Portland State University

PDXScholar

\title{
A study of the relationship between the adolescents' knowledge of laws and their attitudes towards the police
}

Barbara McCallum

Portland State University

Follow this and additional works at: https://pdxscholar.library.pdx.edu/open_access_etds

Part of the Child Psychology Commons, Other Legal Studies Commons, and the Social Work Commons

Let us know how access to this document benefits you.

\section{Recommended Citation}

McCallum, Barbara, "A study of the relationship between the adolescents' knowledge of laws and their attitudes towards the police" (1976). Dissertations and Theses. Paper 1889.

https://doi.org/10.15760/etd.1889

This Thesis is brought to you for free and open access. It has been accepted for inclusion in Dissertations and Theses by an authorized administrator of PDXScholar. Please contact us if we can make this document more accessible: pdxscholar@pdx.edu. 
A STUDY OF THE RELATIONSHIP BETWFEN THE ADOLESCENTS' KNOWLEDGE OF LAWS AND THEIR ATTITUDES

TOWARDS THE POLICE

by

BARBARA MCCALLUM

A practicum submitted in partial fulfiliment of the requirements for the degree of

MASTER OF

SOCIAL WORK ,

Portland State University

1976 
TO THE OFFICE OF GRADUATE STUDIES:

The advisor approves the practicum of Barbara

McCallum presented February 13, 1976.

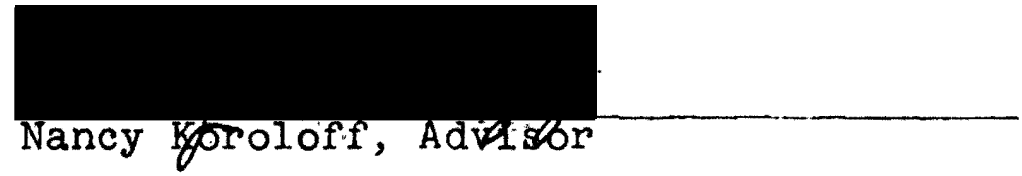

APPROVED:

Gordon Hearn, Dean of School of Soclal Work

Date: $\quad 3-10-76$ 


\section{TABLE OF CONTENTS}

CHAPTER

PAGE

I INTRODUCTION • • . . . . . . . . . . . . 1

II METHODOLOGY . . . . . . . . . . . . 8

Design and Instrument . . . . . . . 8

Sample . . . . . . . . . . . . . . 13

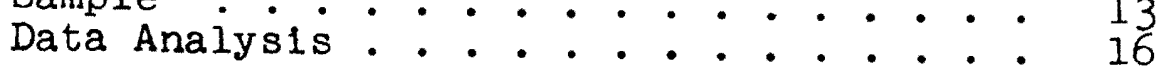

III RESULTS . . . . . . . . . . . . 18

Background . . . . . . . . . 18

Att1tudes ............... . . . . . 22

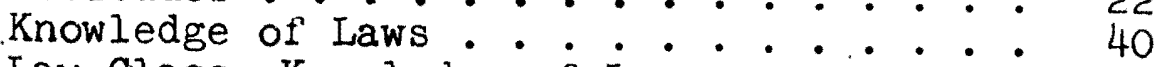

Law Class--Knowledge of Laws . . . . . 49

Law Class--Attitudes . . . . . . . . 50

IV CONCLUSIONS AND RECOMMENDATIONS • • • • 52 BIBLIOGRAPHY . . . . . . . . . . . . . . . 65

APPENDIX A . . . . . . . . . . . . . . . . . 67

APPENDIX B . . . . . . . . . . . . . . . . 75 


\section{CHAPTER I}

\section{INTRODUCTION}

Crime in the United States has risen at an alarming rate in the last few years and along with 1t, juvenile crime and delinquency. Society has had a difficult task trying to deal with this increased juvenile crime. Whereas the destructive, antisocial adult can be placed in prison or jail away from soclety, we are generally reluctant to institutionalize youth in such a manner. Rather, the feeling is that there is still hope for teenagers who commit crimes, that the community rather than institutions can and should be primarily responsible for trying to prevent and/or rehabilitate delinquents.

Law enforcement agencies have responded to this challenge since the mid-1960's by inftiating police-juvenile community programs and creating speclalized Juvenile units with officers specially trained to work with juveniles. ${ }^{1}$

But the police should not, and indeed cannot, be expected to meet the challenge of rising juvenile crime alone. This is particularly true because the police approach to

\section{${ }^{1} 1970$ Survey of Police-Juvenile Operations, complled} by the International Assoclation of Chlefs of Police, 1970. 
crime generally focuses on the pollce-juvenile contact after a delinquent act has been committed. This leaves unattended the need to focus on pre-police contact--on prevention of the delinquent act--and it is to this need that the schools are beginning to respond.

In the fall of 1975, ten school districts in Portland initiated classes designed to teach students about the legal system and the basic concepts related to it such as laws, justice, clvil rights, etc. The explicit goal of this project, as stated by 1 ts director, is "to improve the cltizenship, skills and attitudes of American young people by providing them with an understanding of the law, the legal process and the legal system."2

The theory, then, that the schools are operating under in their response to the challenge of delinquency prevention, is to create more favorable attitudes towards the legal process and system by giving students a better understanding of the process and system. The schools find a rationale for this theory not only from other educators but also from law enforcement analysts and psychologists.

The psychologists supply the basic understanding of how attitudes and behavior are linked:

\footnotetext{
${ }^{2}$ The Oregonian, Tuesday, June 17, 1975.
} 
An attitude is a mental and neural state of read1ness, organized through experience, exerting a directive or dynamic influence upon the individual's response to all objects and situations with which it is related. 3

A positive attitude, then, creates positive behavior by "provoking behavior that is affirmative toward the object or class of objects with which it is related." 4

The psychologists also offer encouragement to educators that by changing the cognitive component of an attitude (by teaching a student new information about laws or police function), there will be reflected a change in the affective (how they feel about the law and police) and behavioral (how they act under the law and with police) components of the student's attitude:

Since there is a tendency for consistency among the components of any attitude, changes in the cognitive component will be reflected in changes in the affective and behavioral components. 5

And finally, the psychologists see the classroom as a good atmosphere in which to handle the kind of reindoctrination that is called for once an adolescent comes to value

${ }^{3}$ Martin Fishbeim, Readings in Attitude Theory and Measurement, p. 8 .

${ }^{4}$ Ibid.

5 Harry Triandis, Att1tude and Att1tude Change, p. 142. 
peer opinion over parental upbringing; 1.e., he must become "acceptable" to have and express more favorable attitudes around other teenagers.

Law enforcement specialists like Edward Eldefonso ${ }^{6}$ and Richard Kobetz 7 also stress the importance of the role schools can play in terms of delinquency prevention via a better understanding of laws and more favorable attitudes. Richard Kobetz, in particular, addresses himself to this concept:

To the extent that individuals within our society fail to encounter or to embrace the social, moral and legal codes of behavior as they are formulated and pronounced by soclety's ruling groups, the delinquent behavior of those persons will continue to violate the personal and property rights of others. 8

Kobetz continues his argument with the thought that delinquent juveniles cannot embrace these social, moral or legal codes if they do not understand them:

Another concept which directs our actions in dealing with youth is the one which holds that juveniles do not understand and have not internalized the soclal, moral and legal codes of our culture. 9 Offender.

${ }^{6}$ Edward Eldefonso, Law Enforcement and The Youthful quency.

$$
\begin{array}{ll}
{ }^{8} \text { Ib1d., p } & 12 . \\
{ }^{9} \text { Ibid., p } 40 .
\end{array}
$$


But it is an educator himself who makes the most eloquent appeal to the schools. In 1965, Dr. Robert Portune, then a graduate assistant at the University of Cincinnati's College of Education, developed a project which was designed to assess juvenile attitudes towards law and law enforcement. Dr. Portune's findings were significant. He discovered that the attitudes of Cincinnati's early adolescents towards the police were nonnegative until a police contact occurred (casual or formal), at which time the attitude became negative. Dr. Portune theorlzed from this that "because of their ignorance of the police mission and function in a free soclety, early adolescents did not possess favorable attitudes sufficiently strong to survive the police contact. 10 Dr. Portune la1d some of the blame on police officers who also reacted from 1gnorance about adolescents and so had some unfavorable attitudes towards juventles, but his main concern was with the role the schools needed to play in order to educate students into forming better attitudes:

Favorable attltudes toward law enforcement. . would seem to constitute one characteristic of the "good cltizen," and the development of such att1tudes is undoubtedly a responsibility of the

${ }^{10}$ Dr. Robert Portune, The Cincinnat1 Police-Juvenile Attitude Project, p. 10. 
Junior high school. In any general national war on crime the compulsory school would seem to have an obligation to improve the police image in the minds of its students.11

It appears, then, that the consensus of those who deal with juvenile crime, from psychologists and educators to law enforcement speclalists, belleve that there is a firm basis to the theory that a better understanding of the law w111 create more favorable attitudes towards the law and its enforcers.

But does the theory actually work? The purpose of this paper is to test some of the implications of this theory to see if it is indeed valid. The method for meeting th1s purpose w1ll involve gathering data from high school age students concerning their attitudes towards the police, their general knowledge of laws, and whether they have taken a class in laws or a law-related subject. If a relationsh1p exists between the se three areas, the schools can be assured of having assumed a proper direction in which to motivate their energies. If no relationship exists, the reasons will be explored in the conclusion of this paper and

${ }^{11}$ Ib1d. 
recommendations will be made to educators for possible changes in the theory they are employing to try to curb the rising tide of delinquency. 


\section{CHAPTER II}

\section{METHODOLOGY}

\section{Design and Instrument}

Using the format of a sample survey, a questionnaire was designed to question high school students, ages sixteen and seventeen, about their attitudes towards the police and their knowledge of laws and their clvil rights (see Appendix A, documents section, for a copy of this questionnaire).

The questionnaire was divided into three parts. The first part contained five questions concerning demographic variables about the student. Here an attempt was made to determine the sex and age of the student, whether his parents had been divorced and whether he was currently I1ving in a single-parent or two-parent family, and the yearly income level of the family. A sixth question was also included in this first part to determine whether the student had ever taken a class about laws or a law-related subject. The information gathered from this first part of the questionnalre was designed to give a focused definition of the sample population (see "Sample" on page 13 of Methodology for a general definition taken from census tract data). 
The second part of the questionnalre concentrated on the students' attitudes towards the police. The questions in this section dealt with the students opinions about the necessity of having police in our soclety, the role of the pollce, how well they do their job, whether they discriminate, and if so, what they discriminate against, whether the students think being a police officer is a worthwhile prof'ession, how much training they think police recelve, whether police understand adolescents, whether they feel they have been treated falrly or unfairly in casual (nonarrest) and formal (arrest or citation) contacts with the police. For this second part, readings in police-juvenile relations prompted many of the questions. In their attempts at better understanding of Juveniles, law enforcement researchers were particularly concerned about the fuveniles' lack of understanding of not only the role and function of police in our soclety, but also of the kind and amount of training police do recelve. The question regarding police discrimination was on the pretest questionnaire and recelved such a large "yes" response that it was decided to pursue this question and determine what it was that students felt was mostly discriminated against. (The possible cholces presented to the students were age, sex, appearance, race, attltude towards the police, and soclal class.) The questions regarding the fairness of treatment by the police 
during casual and formal contacts were designed to elic1t responses from the students regarding their direct experlence with the police.

The final part of the questionnalre dealt with the student's knowledge of civil rights and laws. There were three inftial questions which assessed the student's knowledge about his clvil rights and seven questions about laws which particularly concern adolescents; 1.e., hitchhiking, drugs; loltering, curfew, alcohol in cars. Included with these laws was a question concerning a status offense in which a police officer may detain a juvenile for fallure to mind his parents.

The questionnalre was pretested at a Portland high school in the spring of 1975 . The pretest results showed that some terminology needed to be made simpler and some questions had to be reworded to make it clearer whether one or more answers could be given to a question. The pretest also showed that many students did not know the yearly income of their family, but the question was left in the final questionnalre in hopes that more answers would be recelved in the future.

School "B" was contacted in the late spring of 1975 to request permission for the final questionnaire to be given there. (AIl schools participating in this study have asked to be coded rather than have their school names used. 
Inappropriate use of survey results in the past has made the schools wary of adverse publicity.) School "B" was reluctant to have any more than one hundred questionnaires 1ssued, due to the high demand from other groups and Ind1viduals for the same thing. However, a vice-principal was very helpful in contacting the vice-principals of two other high schools (schools "A" and "C") and securing agreement from them to also have one hundred questionnaires given out in their schools.

In October of 1975, the questionnaires were delivered to the respective schools. Because the schools are so overloaded with requests to participate in surveys and, again, because some schools have had unfavorable experlences with how survey results from their schools were used, a great deal of deference had to be given to the schools in terms of how the questionnaires were to be administered.

Two firm commitments, though, were asked of each school: (1) that the questionnaires be given to only the Junior class (sixteen and seventeen year olds) and (2) that the questionnaires be given on a random selection basis to classes that ranged throughout the day and were required of all Juniors. All the schools met the first commitment with no trouble. The second commitment, however, recelved some variation. School "A" used a sort of systematic random selection. Because this school tracks its classes by 
ability, a random selection could have resulted in the questionnaire being given solely to all above average or all bélow average students. In order to avold this, the viceprincipal of school "A" systematically separated social studies classes (required of all juniors) according to their student ablilty make-up, and then he randomly selected one class from each level of below average, average, and above average. School "B" used only one soctal studies teacher and had her administer the questionnaire to her three classes. These classes did range throughout the day and social studies is required of all funiors at this school, but the fact that only one teacher was used decldedly reduced the randomness of selection that was asked of the schools. School "C" best met the commitment of random selection. As with the other two schools, social studies were required of all juniors and from the avallable soctal studies classes the vice-principal made a random selection of three classes ranging from morning to afternoon and being taught by different teachers.

The questionnaires were left with the schools, to be administered by the teachers. Within ten days, all of the questionnalres were completed and had been collected for the data analysis. 
Sample

School "B" was originally picked because the location enables it to draw students from a diversity of socioeconomic backgrounds. The addition of school "A" momentarily changed the well-rounded representation of school "B's" student base, since school "A" draws its students from lower economic backgrounds. But the final addition of school "C" swung the sample back to a more representative base by including generally higher socio-economic neighborhoods .

After contacting the Portiand School District Information Center and recelving a map of Portland school districts, the school districts were matched to the census tracts on the map avallable in the 1970 Census of Population and HousIng. Since the school districts do not match the census tracts, this was a very exacting task involving difficult decisions in some cases as to whether a district line included some or any of a particular census tract. In addition, the information in this census is five years old, but It is the most recent census that has been taken. For these reasons, then, it has to be noted that the following information about the area each of the high schools draws its students from is only a general representation of that area. 
(For the specific sample population of students answering the questionnaire, see Chapter III, "Results," page 18.)

School "A." Using a composite of the twelve census tracts that school "A" draws students from, elght have a Caucasian population with less than 1 per cent nonCaucasian. Three tracts have greater than 1 per cent (but still not over 2 per cent) non-Caucasian. One tract, however, has a 54 per cent non-Caucasian population. Of the famllies in this area, 80 per cent are headed by both a husband and a wife, while 16 per cent are headed by a female only; the remaining 4 per cent are headed by "other male head."* Approximately 52 per cent (ranging from 38 per cent to 69 per cent) of the adults over twenty-flve have completed their high school education. The two most common occupations for the people who live in this area are clerical and service workers.** The yearly income range for the area falls between $\$ 4,682$ and $\$ 12,687$.

School "B." Using a composite of the ten census tract areas that comprise this school's district, eight have a Caucasian population w1th less than 1 per cent non-Caucasian.

* "Other male head" defined by the Census as "male who heads household but is not related to family by blood or marrlage." **"Service workers" defined as "cleaning and food ser-
vice, protective service, personal and health service." 
Two tracts have over 1 per cent non-Caucasian, but in neither of these tracts is this population over 2 per cent. of the marital status of the families in the area, 85 per cent of the families are headed by both a husband and a wife, wh1le 13 per cent are headed by a female only, (the remaining 2 per cent are headed by "other male head"). Of the adults in this area who are over twenty-five years of age, approximately 57 per cent (ranging from 34 per cent to 82 per cent) have completed high school. The two most common professions for those who live in this area are clerical and craftsmen.* The yearly income range for the area falls between $\$ 9,256$ and $\$ 15,281$.

School "C.". This school draws its students from nine census tracts. Caucaslans are in the clear majority as all nine tracts contain less than one-half of 1 per cent nonCaucasian. Ninety per cent of the families in this area are headed by both a husband and a wife, while 8 per cent are headed by a female alone (the remaining 2 per cent are headed by "other male head"). Of those adults who are over twenty-five, approximately 81 per cent (ranging from 70 per cent to 91 per cent) have completed their high school education. Clerical and professional are the two most common

\footnotetext{
* "Craftsmen" defined as "construction craftsmen, mechanics, and repairmen."
} 
occupations of those who live in this area. The yearly income ranges from $\$ 11,341$ to $\$ 19,843$.

Again, it should be noted that the above demographic data concerning each school's area should be viewed as approximations due to the census tract information being five years old and the difficulty which resulted when school districts and census tract areas did not exactly match.

\section{Data Analysis}

After the questionnalres were collected from the schools, they were coded by school and an identification number was assigned each individual questionnaire. The data was then key-punched and a tally program was run to generate frequency tables. From the frequency tables the attitudes and knowledge of laws of the total student sample from each school could be ascertained (see Tables V through XXIX, Chapter III, "Results"). A second program was run to compute each student's individual score on the questions regarding knowledge of laws (see Table XXXV, Appendix B). In addition to individual scores, this program also gave a mean score by school. A mean knowledge score was then computed for each student who sald he had taken a previous class about laws, and these means were compared with the mean knowledge scores of those students who had not taken such a class (see Table XXX, Chapter III, "Results"). 
Finally, the students who had taken a previous law class were again singled out and their attitude responses were tallied. The number and per cent of these students' responses (In terms of favorable or negative attitudes) were then compared with the number and per cent of students responding who had not taken a previous law class (see Tables XXXVI through XL, Appendix B). 
CHAPTER III

RESULTS

The data from the questionnaires w11l be presented in tables. Any information not found in tables in this section can be located in the Appendix.

Due to computer rounding, some percentage totals are slightly more or less than one hundred per cent.

Bàckground

of the three schools participating in the study, the breakdown of the sex and age range of the responding students is as follows:

School "A's" responding student population is 43 per cent male and 57 per cent female (see Table XXXI, Appendix B). The age range for this school is from fifteen to nineteen years. The percentage of respondents is falrly evenly distributed over the fifteen to seventeen year olds, with only a small number of elghteen and nineteen year olds. Of the three schools, school "A" has the largest percentage of responding students who are fifteen years old (see Table XXXII, Appendix B).

School "B's" responding student population is 41 per cent male and 59 per cent female (see Table XXXI, Appendix 
B). The age range for this school is from fifteen to elghteen years of age. The sixteen and seventeen year olds are the majority with only a small number of fifteen and elghteen year olds (see Table XXXII, Appendix B).

School "C's" responding student population is 63 per cent male, 37 per cent female (see Table XXXI, Appendix B). The age range for this school is also from fifteen to eighteen years. As with school " $B$ " the majorlty of students are sixteen and seventeen years old, although in this school "C" the sixteen year olds are predominant. There are few f'lfteen and eighteen year olds (see Table XXXII, Appendix B).

In all three schools, approximately one-third of the students responding are not currently living with both their natural parents:

\section{TABLE I}

ARE YOU CURRENTLY LIVING WITH BOTH YOUR NATURAL FATHER AND MOTHER?

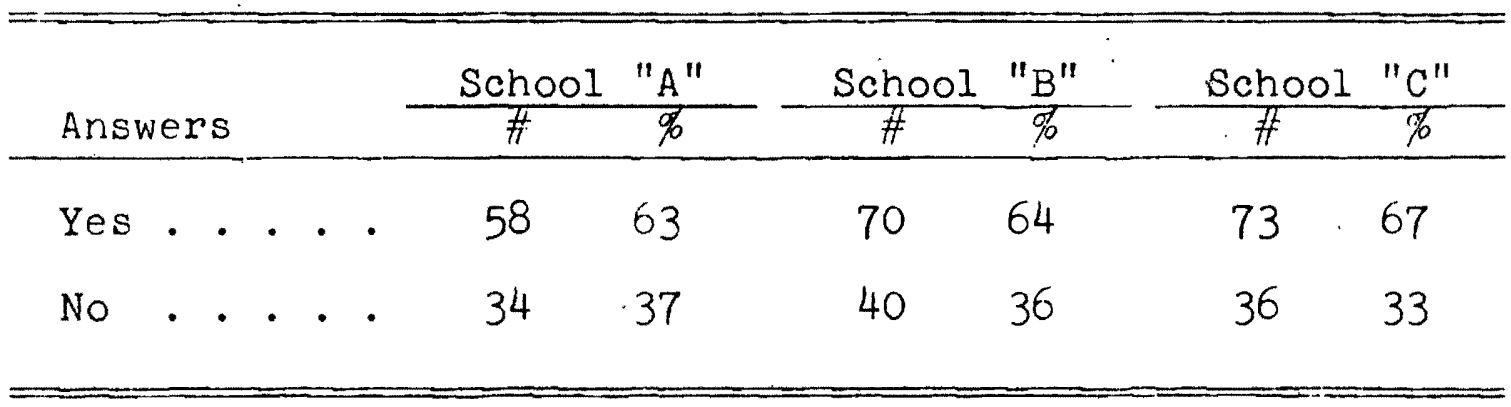


These students who are not living with both their natural parents were asked with whom they were living, and al,though 13 per cent of the 26 per cent of students responding from school "A" said they were in a two-parent family, "mother and step-father," both school "B" and school. "C" had most of their students (18 per cent out of 37 per cent for school "B" and 17 per cent out of 33 per cent for school "C") living in single-parent "mother only" families:

\section{TABLE II}

IF YOU ARE NOT CURRENTLY LIVING WITH BOTH YOUR NATURAL PARENTS, WITH WHOM ARE YOU CURRENTLY LIVING?

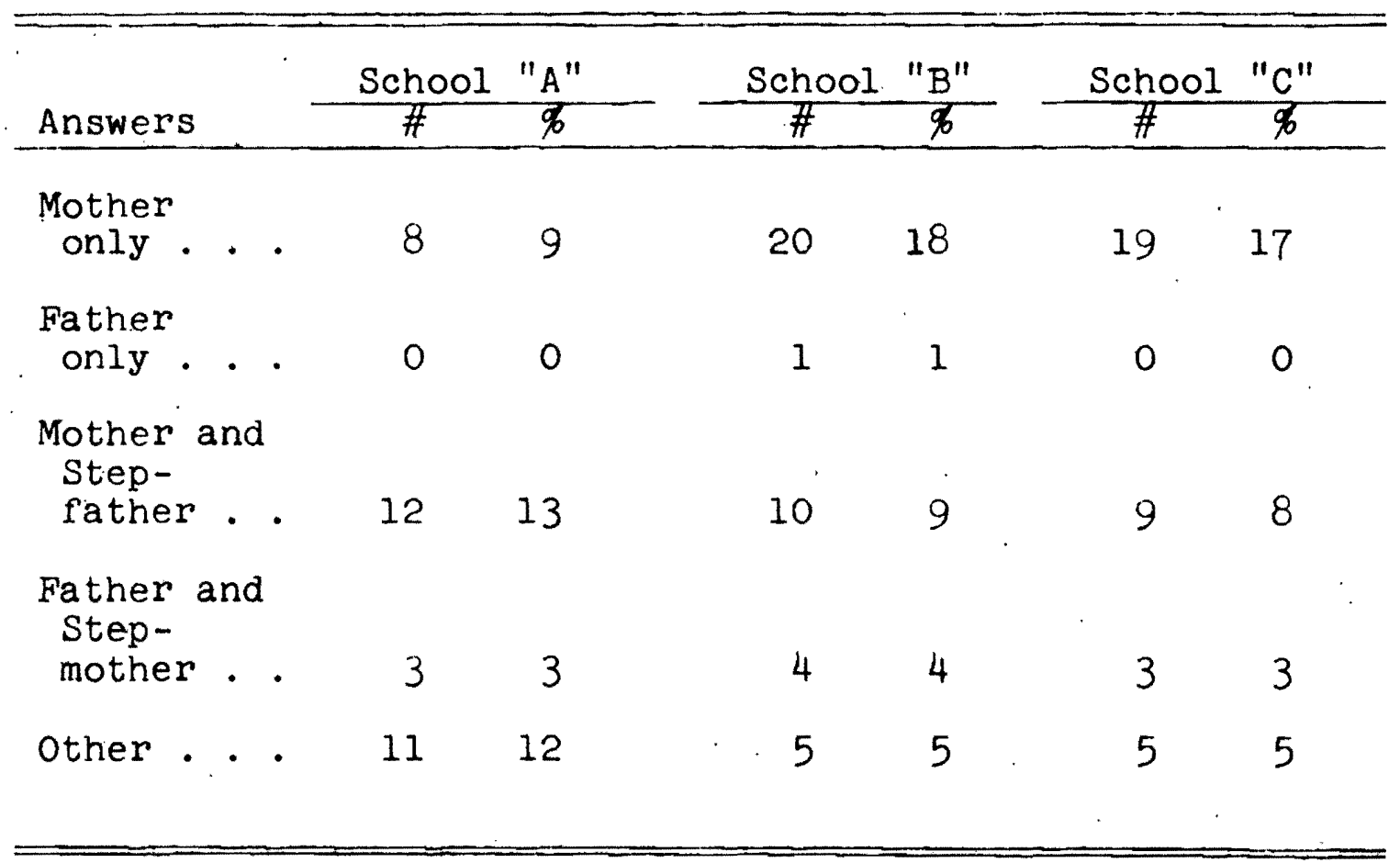


The income level for each school corresponded closely with the 1970 Census data--school "A" had the lowest income level, school "B" had a middle income level, and school "C" had the highest level. It should be noted, though, that the "no response" to this income question ranged from 15 per cent to 23 per cent for the schools.

TABLE III

WHAT IS THE YEARLY INCOME LEVEL OF YOUR FAMILY

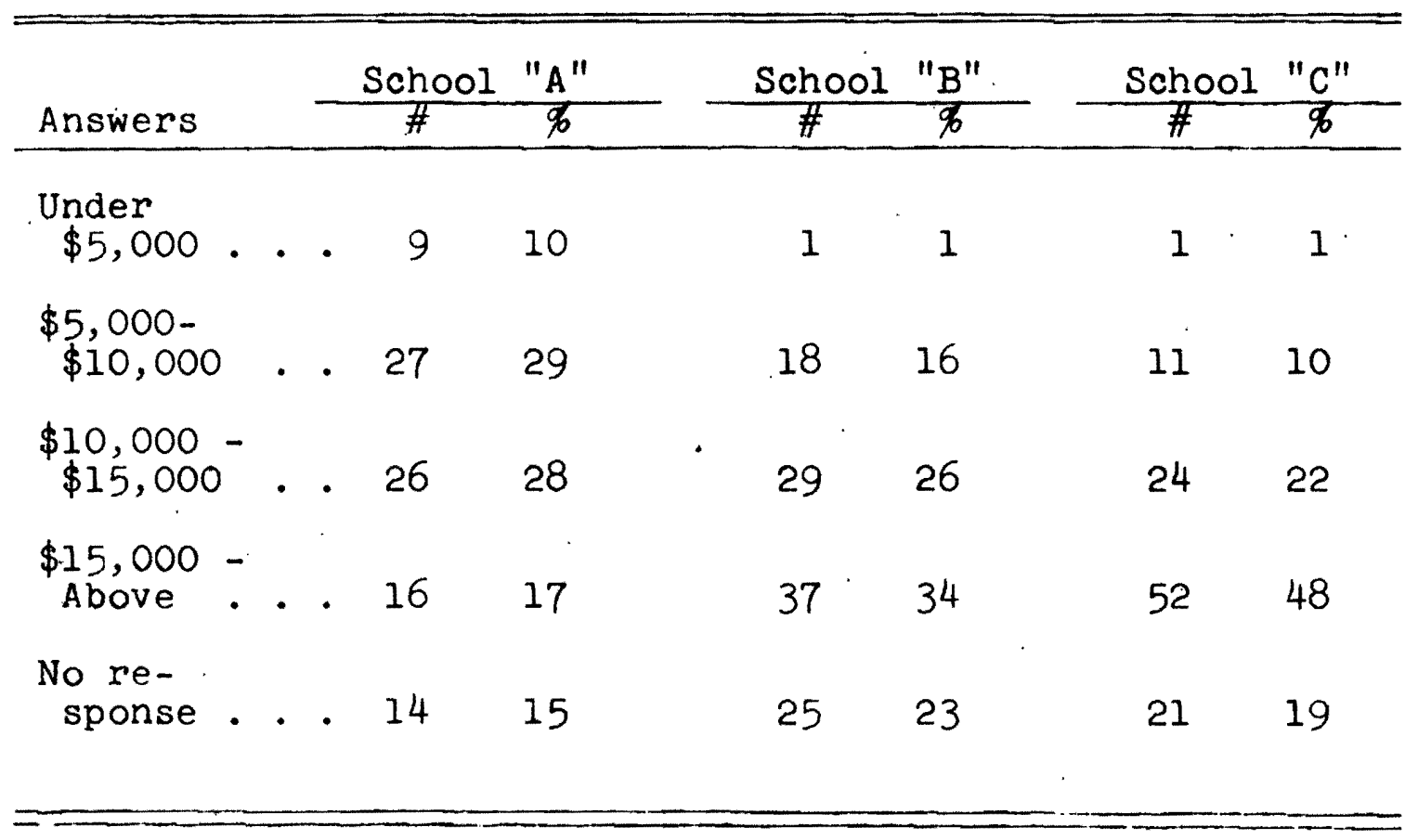

An important finding resulted from the last question on the background part of the questionnalre. This question asked students if they had ever taken a class devoted entirely to studying laws or law-related subjects. Fifty-four 
per cent of the students from school "B" responded "yes," while only 25 per cent of school "A's" students said "yes," and even fewer students (15 per cent) from school "C" responded "yes."

\section{TABLE IV}

HAVE YOU EVER TAKEN A CLASS IN SCHOOL DEVOTED ENTIRELY TO TEACHING YOU ABOUT LAWS OR

IAW-RELATED SUBJECTS LIKE CIVIL RIGHTS?

\begin{tabular}{|c|c|c|c|c|c|c|c|c|c|c|c|}
\hline \multirow{2}{*}{\multicolumn{5}{|c|}{ Answers }} & & \multirow{2}{*}{$\frac{\text { Schoo }}{\#}$} & \multirow{2}{*}{ "A" } & \multirow{2}{*}{$\frac{\text { School }}{\#}$} & \multirow{2}{*}{$\frac{\text { "B" }}{\not o}$} & \multirow{2}{*}{$\frac{\text { School }}{\#}$} & \multirow{2}{*}{$\frac{{ }^{\prime C} "}{\%}$} \\
\hline & & & & & & & & & & & \\
\hline Yes & . & . & . & - & • & 23 & 25 & 59 & 54 & 16 & 15 \\
\hline No & - & - & . & - & • & 68 & 74 & 49 & 45 & 93 & 85 \\
\hline No & res & po & nse & & - & 1 & 1 & 2 & 1 & 0 & 0 \\
\hline
\end{tabular}

\section{Attitudes}

There are two major patterns concerning the students' attitudes which should be noted before looking at the individual attitude questions. First, there is a fairly consistent similarity in the responses of the students from all three schools. Second, although the attitude responses were 
so often similar, the students from school " $B$ " answered slightly more positively on a continuum.

\section{TABLE V}

DO YOU THINK IT IS NECESSARY TO HAVE POLICE IN OUR SOCIETY?

\begin{tabular}{|c|c|c|c|c|c|c|c|}
\hline & & School & "A" & Sehool & "B" & School & "C" \\
\hline Answers & & \# & 96 & $\#$ & $\%$ & $\#$ & $\%$ \\
\hline Yes $\cdot \cdot \cdot$ & • & 77 & 84 & 104 & 95 & 102 & 94 \\
\hline $\begin{array}{l}\text { Only in } \\
\text { some in- } \\
\text { stances }\end{array}$ & - & 15 & 16 & 5 & 5 & 5 & 5 \\
\hline$\cdot \cdot \cdot$ & $\cdot$ & 0 & 0 & 0 & 0 & 0 & 0 \\
\hline No response & • & 0 & 0 & 0 & 0 & 2 & 1 \\
\hline
\end{tabular}

All the students generally responded favorably to this question with an unconditional "yes." School "A" did have more students that qualified their "yes" response with "only in some instances." None of the students felt that police were unnecessary in our soclety. 
TABLE VI

WHAT IS THE MOST IMPORTANT FUNCTION

OF THE POLICE?

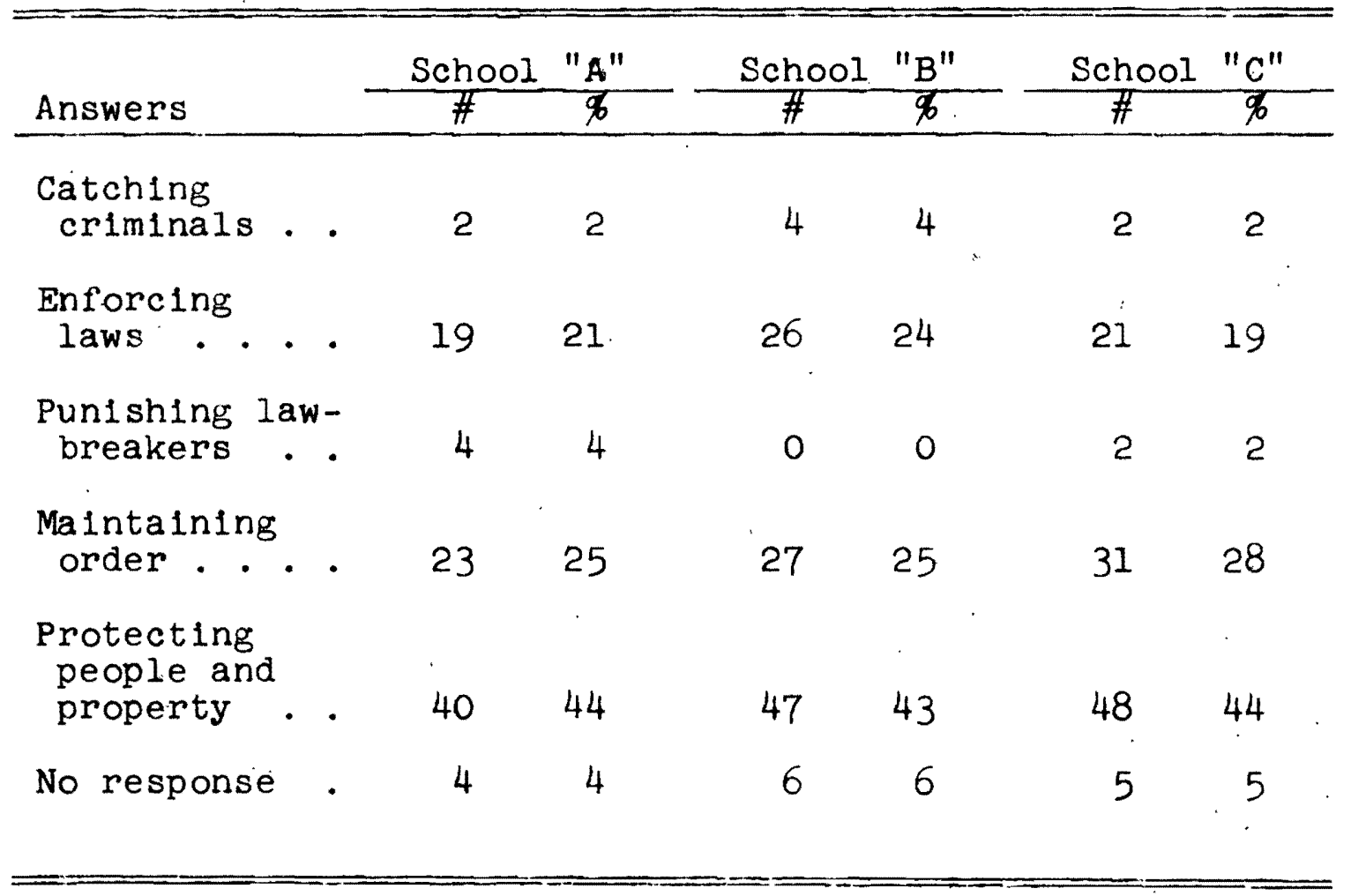

This is an example of the similarity of response among the schools. The percentage of response for each possible police function was very much the same for each school.

The very negative police function of "punishing lawbreakers" was chosen by the least number of students. Another police function which is not negative but that suggests a more aggressive function--"catching criminals"--also had a low response from all students. "Enforcing laws" and 
"maintaining order"--police functions which are considered authoritarian but less aggressive--recelved the next most frequent response. The police function which had the highest response from all schools was "protecting people and property," a less authoritarian and almost benevolent function.

TABLE VII

HOW WELL DO YOU THINK THE POLICE DO THEIR JOB OF PROTECTING PEOPLE?

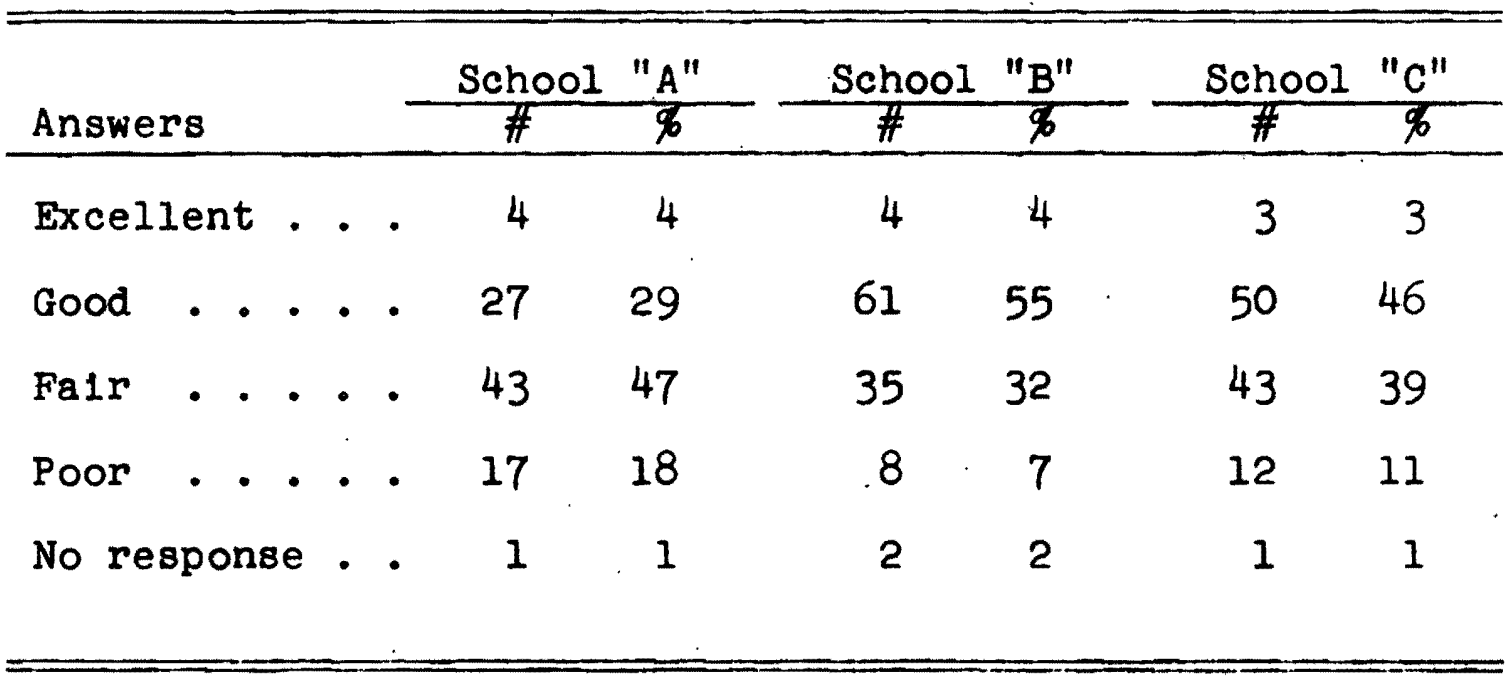

Since so many of the students felt this protecting people was the most important police function, their response to this question is pertinent in discerning their attltude towards the police. Again, the similarity of response is evident in that none of the schools had over 4 per cent of the students give the police a rating of "excellent." 
Here, though, the students from school "B" begin to pace themselves ahead of the other schools as 55 per cent of the students respond that the police do at least a "good" job of protecting people. The students from school " $\mathrm{C}$ " gave the next most frequent "good" response (46 per cent), while students from school "A" most frequently responded with only "fair" (47 per cent). The students from school "A" also reported more "poor" Job performance (18 per cent) than students from elther school " $B$ " (which had the lowest response to "poor"-_..7 per cent), or school "C" (11 per cent).

\section{TABLE VIII}

HOW WELL DO YOU THINK THE POLICE DO THEIR JOB OF ENFORCING LAWS?

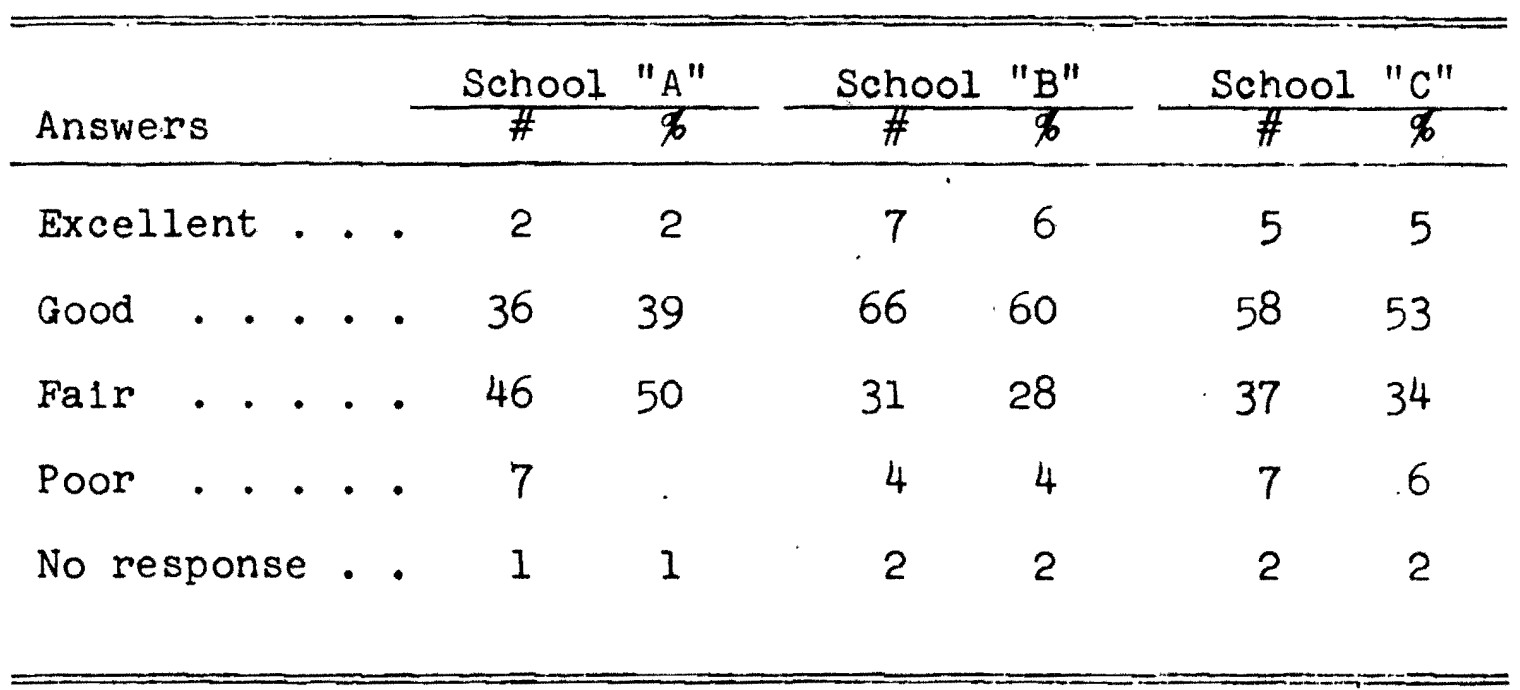

This police function was also considered to be 1mportant by many students. Again, the students from all schools 
were reluctant to give the police a rating of "excellent." And again, students from school " $B$ " and school " $C$ " gave them a "good" rating with students from school " $B$ " responding "good" with the greatest frequency (60 per cent). Students from school "A" continued to give the police only a "fair" rating ( 50 per cent).

This response differed from the students' evaluation of how well the pollce protect people in that the students generally responded less to the "poor" rating for enforcing laws. The students, then, rated the police's job performance in enforcing laws better than their performance in protecting people.

TABLE IX

DO YOU THINK THE POLICE TREAT EVERYONE THE SAME?

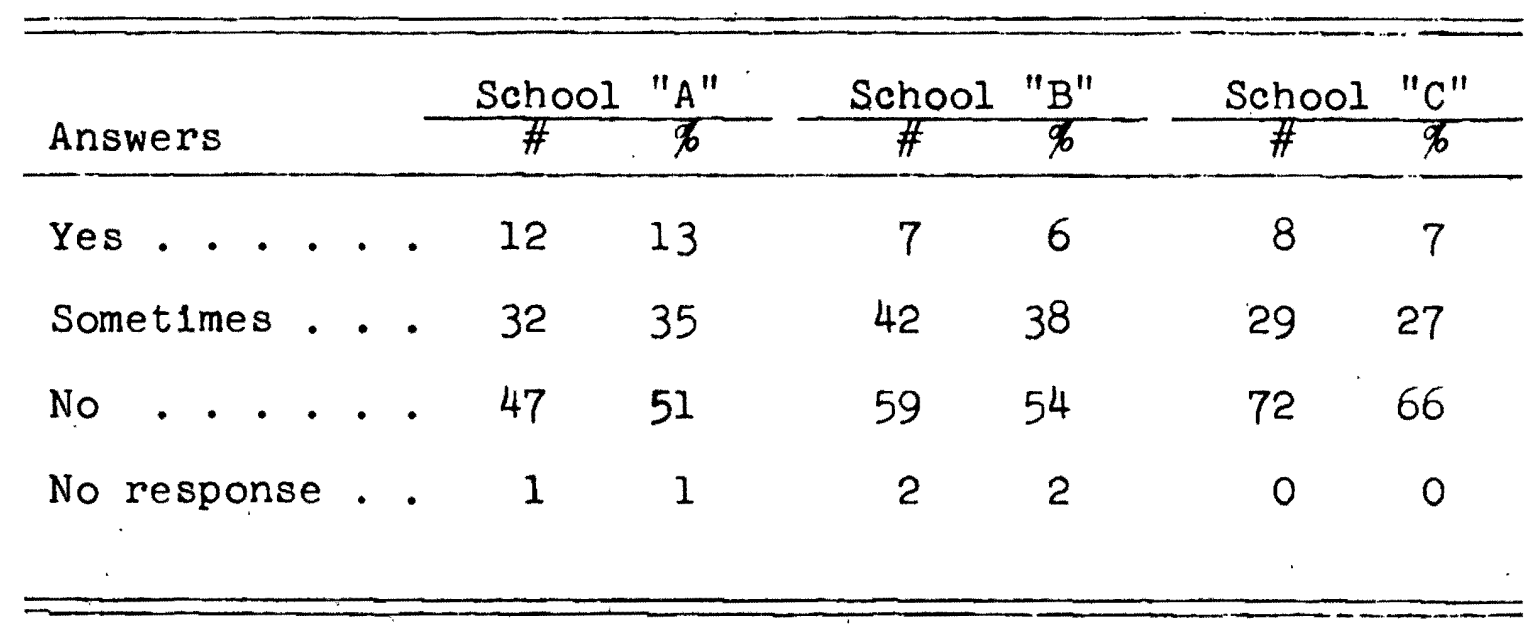

This question was asked, not to determine an attitude stance so much as to act as a preamble for a question 
concerning what it is students feel police discriminate against--a more relevant concern in determining student attitudes.

An interesting result which should be noted is that where students from school "A" gave the police only "falr" ratings for job performance in protecting people and enforcing laws (see Tables VII and VIII), they answered--with more frequency (13 per cent) than students from school "B" ( 6 per cent) or school "C" (7 per cent)--that "yes," police do treat everyone the same. Conversely, where school " $B$ " and school " $C$ " had given the police "good" Job ratings, they answered with the most frequency (school "B" 54 per cent, school "C" 66 per cent) that "no," police do not treat everyone the same. 
TABLE X

WHAT ARE THE TWO THINGS THE POLICE

MOST DISCRIMINATE AGAINST?

\begin{tabular}{|c|c|c|c|c|c|c|c|}
\hline Answers & & $\frac{\text { School }}{\#}$ & "A" & $\frac{\text { School }}{\#}$ & $\frac{\text { "B" }}{\text { क }}$ & $\frac{\text { School }}{\#}$ & $\frac{\text { "C" }}{9}$ \\
\hline Age . . . & & 24 & 26 & 44 & 40 & 40 & 38 \\
\hline $\operatorname{Sex} \cdot \cdot \cdot \cdot$ & . & 4 & 4 & 6 & 6 & 4 & 4 \\
\hline Race . . & . & 24 & 27 & 19 & 17 & 22 & 21 \\
\hline Appearance & . & 33 & 36 & 48 & 44 & 51 & 46 \\
\hline $\begin{array}{l}\text { Attitude } \\
\text { towards } \\
\text { pol1ce. }\end{array}$ & - & 50 & 55 & 55 & 49 & 39 & 36 \\
\hline $\begin{array}{r}\text { Social } \\
\text { class }\end{array}$ & - & 10 & 11 & 14 & 13. & 15 & 14 \\
\hline No response & - & 15 & 17 & 17 & 15 & 31 & 28 \\
\hline
\end{tabular}

The students were given six possible answers to this question and were asked to plck two that they felt the police most discriminated against. The number of responses were added together and percentages were flgured on the total number of responses for each answer.

Overall, the students gave very similar responses. "Sex" recelved the least response from all the students, "soclal class" was the next lowest, followed by "race." "Age" and "appearance" were very close and recelved a fairly 
large response. "Attitude towards the police" was the most frequent response from students at two of the three schools--"A" (55 per cent) and "B" (49 per cent). Students from school " $C$ " answered "appearance" the most often (46 per cent).

Individually, students from school "A" differentiated themselves by responding more frequently than the students from the other schools that "race" was discriminated against (27 per cent), and least frequently that "age" was discrimInated against (26 per cent). Students from school "B" differentiated themselves by responding most frequently to "attitude towards the police" (49 per cent), and next most frequently to "appearance" (44 per cent). Students from school "C" responded differently in that "appearance" was the most frequent response ( 46 per cent), followed by "age" (38 per cent).

Important to note, finaliy, is the fact that students from at least two of the three schools--"A" and "B"--were well aware of the importance of their own attitude towards the police in terms of how the police will react to them. 


\section{TABLE XI}

DO YOU THINK THAT BEING A POLICEMAN

IS A WORTHWHILE PROFESSION?

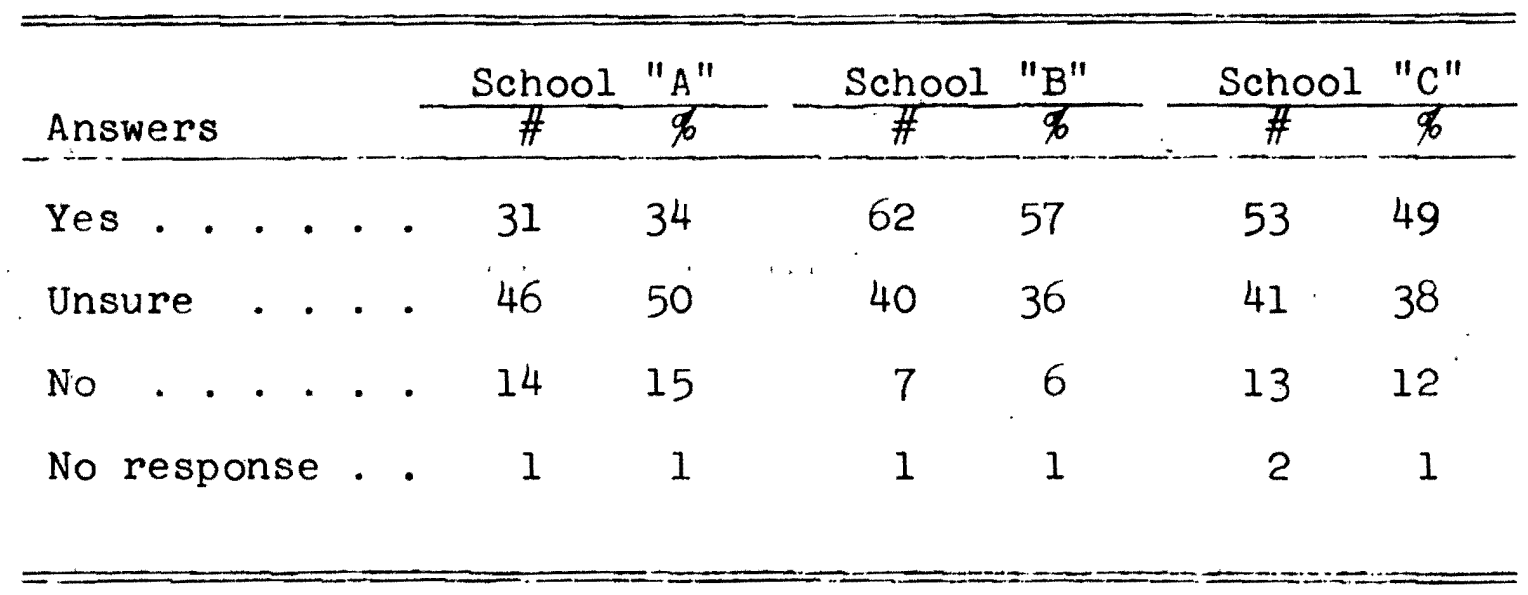

Here students from school "B" showed themselves again as being more favorably inclined towards the police. Fifty-seven per cent of "B's" students said "yes," being a policeman is a worthwhile profession (and conversely, a smaller percentage of school "B's" students answered "no."

Students from school "C" followed those from school "B" in judging that "yes,". being a policeman is a worthwhile profession (49 per cent). Fifty per cent of school "A's" students, however, felt "unsure" about whether it is a worthwhile profession.

Another question, also on the questionnalre, relates to the worthiness of the policeman's job. This question is, "Have you ever considered a career as a policeman or policewoman?" (See Table XXXIII, Appendix B.) The answers were 
interesting in that all the students responded with almost the exact same low percentage to the reply "yes and st11l do" (16 per cent for school "A," 14 per cent for school "B," 14 per cent for school " $\mathrm{C}$ "). The majority response for all students--although varying this time in percentage--was "no and still don't" (46 per cent for school "A," 34 per cent for school "B," 37 per cent for school "C"). The indication here is that the students' consideration of the worthiness of the profession does not seem to affect whether they would choose it as a career.

\section{TABLE XII}

DO YOU THINK THAT POLICE IN GENERAL UNDERSTAND ADOLESCENTS?

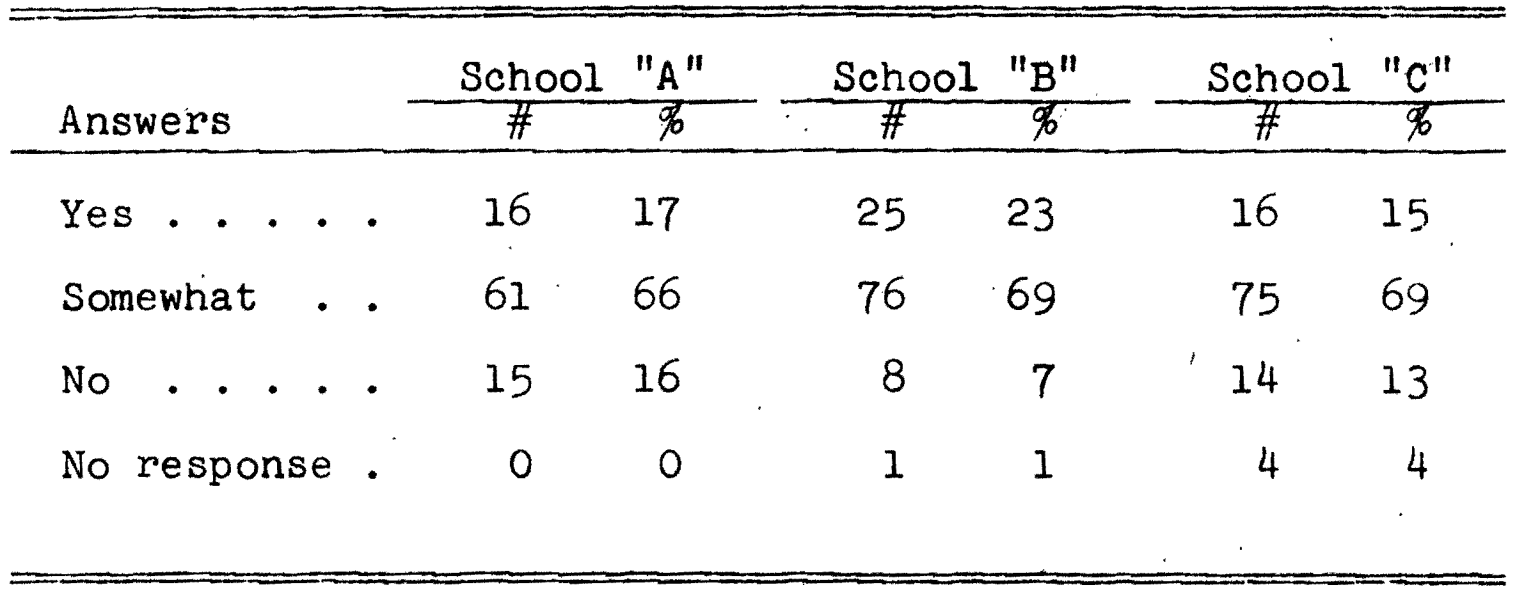

Students from school "B" continued their trend towards more favorable attitudes in their response to this question also--23 per cent of students from school "B" answered "yes," pollce understand adolescents, and only 7 per cent answered 
"no." Students from school "A" and school "C" responded about the same to this question (school "A," 17 per cent "yes," and 16 per cent "no"; school "C," 15 per cent "yes," and 13 per cent "no"), which is different from other questions when school " $C$ " followed closely behind school "B" with school "A" responding least positively.

TABLE XIII

HOW MUCH SPECIAI POLICE TRAINING DO YOU THINK POLICE RECEIVE BEFORE THEY ARE PUT ON THE FORCE?

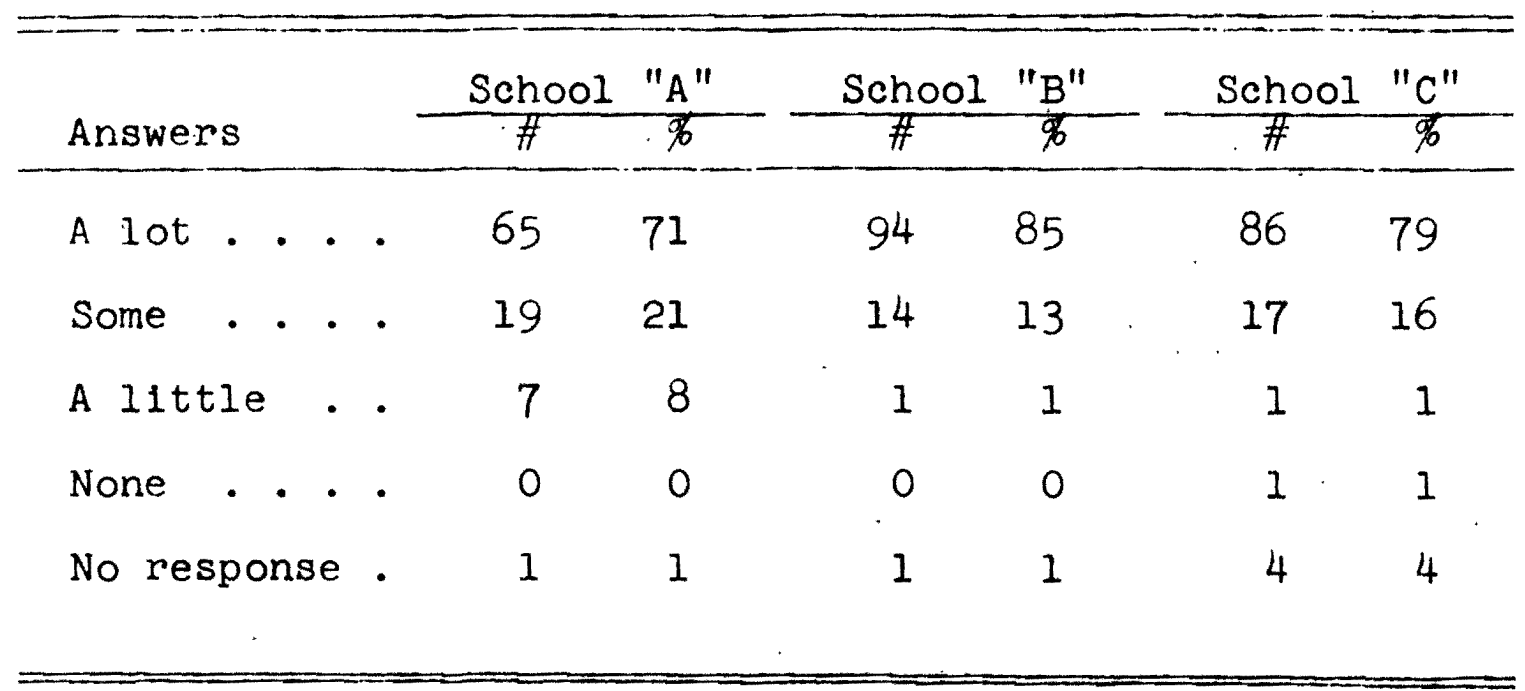

The response to this question is interesting. Whereas the students had differed on how well the police do their job, whether their profession is worthwhile, and if they understand adolescents, they all felt that the police recelve a lot of special training before they are put on the force. 
TABLE XIV

HOW MANY CASUAL CONTACTS HAVE

YOU HAD WITH POLICE?

\begin{tabular}{|c|c|c|c|c|c|c|c|}
\hline & & School & "A" & School & "B" & School & "C" \\
\hline Answers & & $\#$ & $\%$ & $\#$ & $\%$ & $\#$ & $\%$ \\
\hline $\begin{array}{l}\text { Many } \\
\text { (over 15) }\end{array}$ & & 13 & 14 & 20 & 18 & 10 & 9 \\
\hline $\begin{array}{c}\text { Moderate } \\
(8-15)\end{array}$ & & 16 & 17 & 16 & 15 & 24 & 22 \\
\hline $\begin{array}{l}\text { Few } \\
(1-8) .\end{array}$ & & 49 & 53 & 65 & 59 & 67 & 61 \\
\hline None . . & & 13 & 14 & 8 & 7 & 8 & 7 \\
\hline No response & & 1 & 1 & 1 & 1 & 0 & 0 \\
\hline
\end{tabular}

This question was designed to elicit information about how often teenagers are coming into contact with the police on an informal, nonthreatening basis (see Questionnalre, Appendix A, for a more detalled defintion of a casual contact).

As with the attitude responses, there was a similarity of response among the students. A "few" contacts (one to elght) was the most frequent response from all students (53 per cent for school "A"; 59 per cent for school "B"; 61 per cent for school " $\mathrm{C}$ "). 
School "A" distinguished itself from the other two schools by a much larger response of "no casual contacts." School "C" differentiated itself by a moderately lower response to "many" contacts ( 9 per cent) than elther school "A" (14 per cent) or school "B" (18 per cent).

TABLE XV

IN THESE CASUAL CONTACTS WITH THE POLICE, HOW HAVE YOU BEEN TREATED?

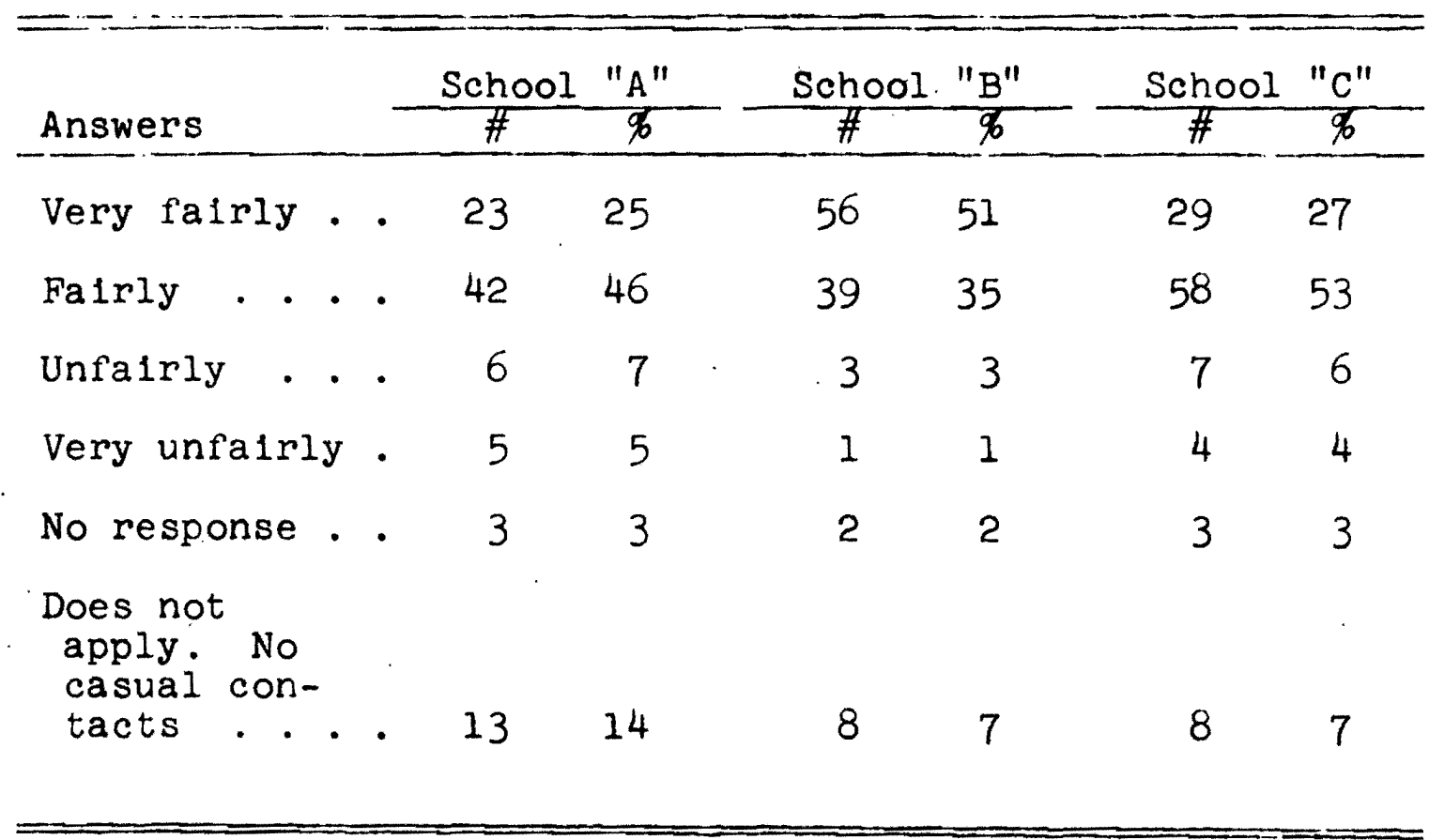

Here students from school "B" showed a considerably more favorable response with 51 per cent of the students answering that they had been "very falrly" treated by the 
police in casual contacts. (School "A" had a 25 per cent "very falrly" response, school "C" a 27 per cent "very falrly").

Adding together the percentages of. "very falrly" and "falrly" responses, 71 per cent of the students from school "A" expressed that they recelved favorable treatment from the police, 86 per cent of the students from school "B" expressed favorable treatment, and 80 per cent of the students from school " $C$ " judged their treatment as favorable.

TABLE XVI

HAVE YOU EVER BEEN PICKED UP, CITED, DETAINED, OR ARRESTED BY THE POLICE?

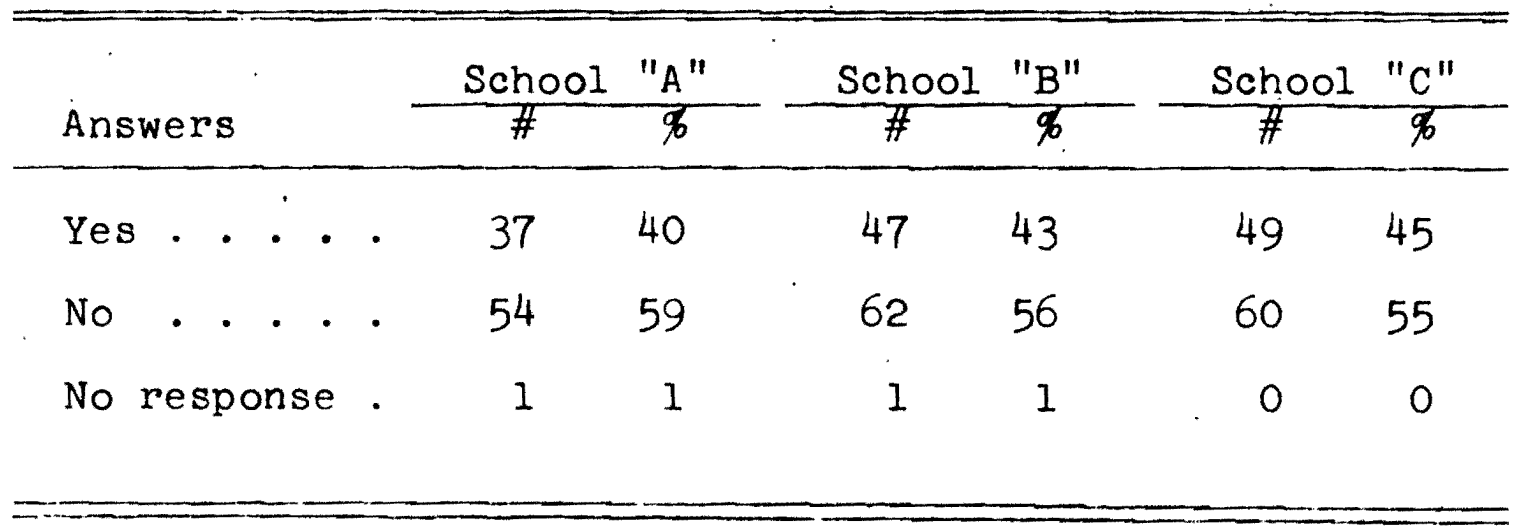

The trend towards similarity of response showed up clearly here. All of the students were just about evenly divided on this question. A little over 40 per cent of the students from each of the schools had been plcked up, cited, 
detained or arrested by the police, while a little over 50 per cent of the students from each school had not had this formal contact with the police.

TABLE XVII

HOW MANY FORMAL CONTACTS HAVE YOU

HAD WITH THE POLICE?

\begin{tabular}{|c|c|c|c|c|c|c|c|}
\hline \multirow{2}{*}{\multicolumn{2}{|c|}{ Answers }} & \multicolumn{2}{|c|}{ School "A" } & \multicolumn{2}{|c|}{ School "B" } & \multicolumn{2}{|c|}{ School "C" } \\
\hline & & $\#$ & क & $\#$ & क & $\#$ & क \\
\hline $\begin{array}{l}\text { Many } \\
\text { (over 15). }\end{array}$ & . & 0 & 0 & 1 & 1 & 1 & 1 \\
\hline $\begin{array}{l}\text { Moderate } \\
(8-15)\end{array}$ & - . & 2 & 2 & 4 & 4 & 2 & 2 \\
\hline $\begin{array}{l}\text { Few } \\
(1-8)\end{array}$ & - . & 33 & 36 & 42 & 38 & 46 & 42 \\
\hline No response & • & 4 & 4 & 0 & 0 & 0 & 0 \\
\hline $\begin{array}{l}\text { Does not } \\
\text { apply. No } \\
\text { formal con- } \\
\text { tacts... }\end{array}$ & . & 54 & 59 & 62 & 56 & 60 & 55 \\
\hline
\end{tabular}

of the students who had had formal contact with the police, the trend towards similar experiences continued with most of the students responding that they had had a "few" (1-8) formal contacts with the police ( 36 per cent for school "A"; 38 per cent for school "B"; 42 per cent for school "C"). 
TABLE XVIII

HOW WERE YOU TREATED BY THE POLICE

DURING THESE FORMAL CONTACTS?

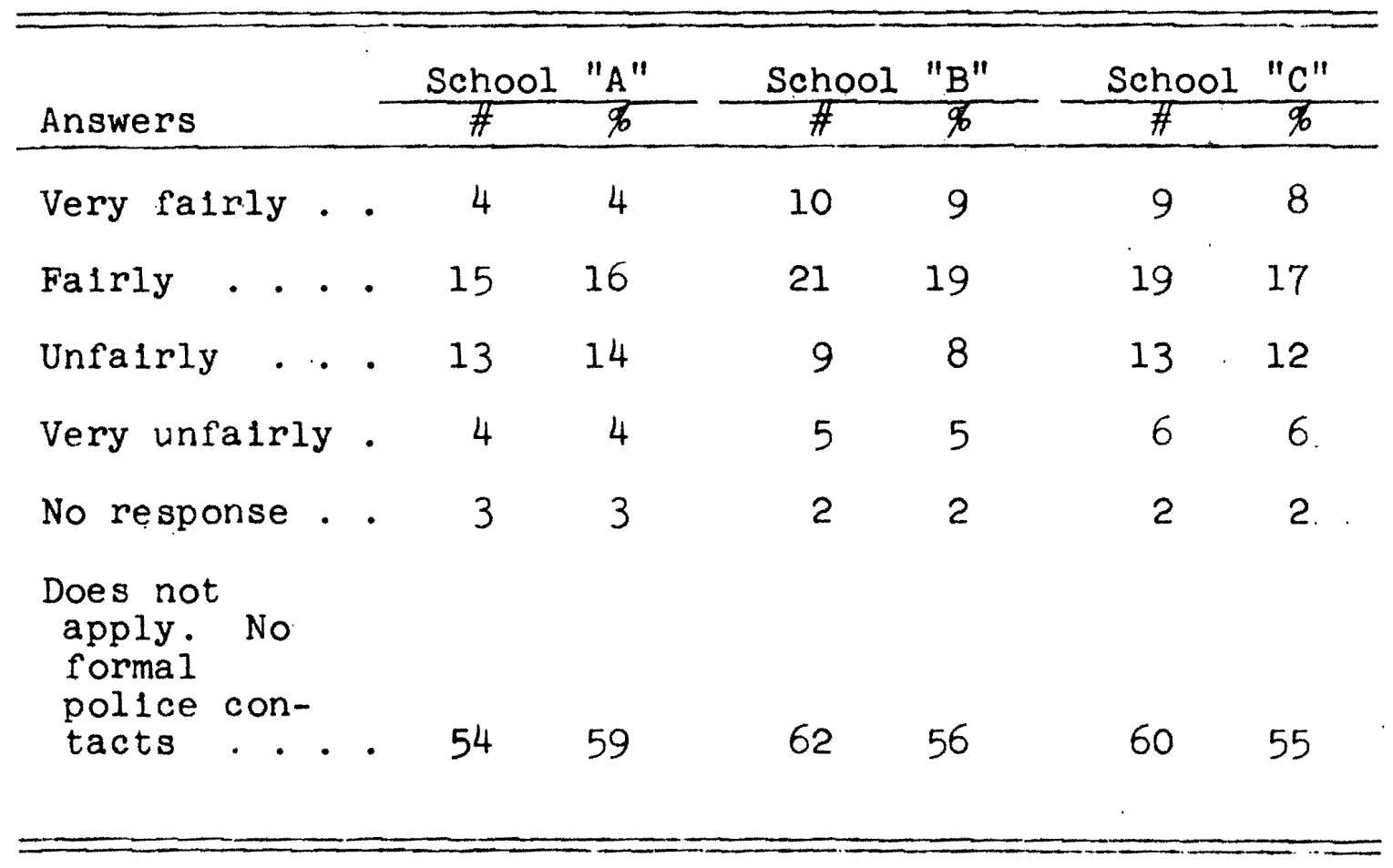

Students from school "B" did not come out as noticeably ahead in positive responses here as they did in their responses concerning treatment in casual contacts.

Again, adding together the "very falrly" and "falrly" responses made by the students, students from school " $B$ " had a 28 per cent favorable treatment response; students from school "C" had a 25 per cent response, and students from school "A" had a 20 per cent response. 
Interesting here is that each of the schools had almost the same percentage of students answering "very unfairly" ( 4 per cent for school "A"; 5 per cent for school "B"; and 6 per cent for school "C").

TABLE XIX

WERE YOU INVOLVED IN AN ACTIVITY YOU KNEW TO BE ILLEGAL WHEN YOU HAD FORMAL CONTACT WITH THE POLICE?

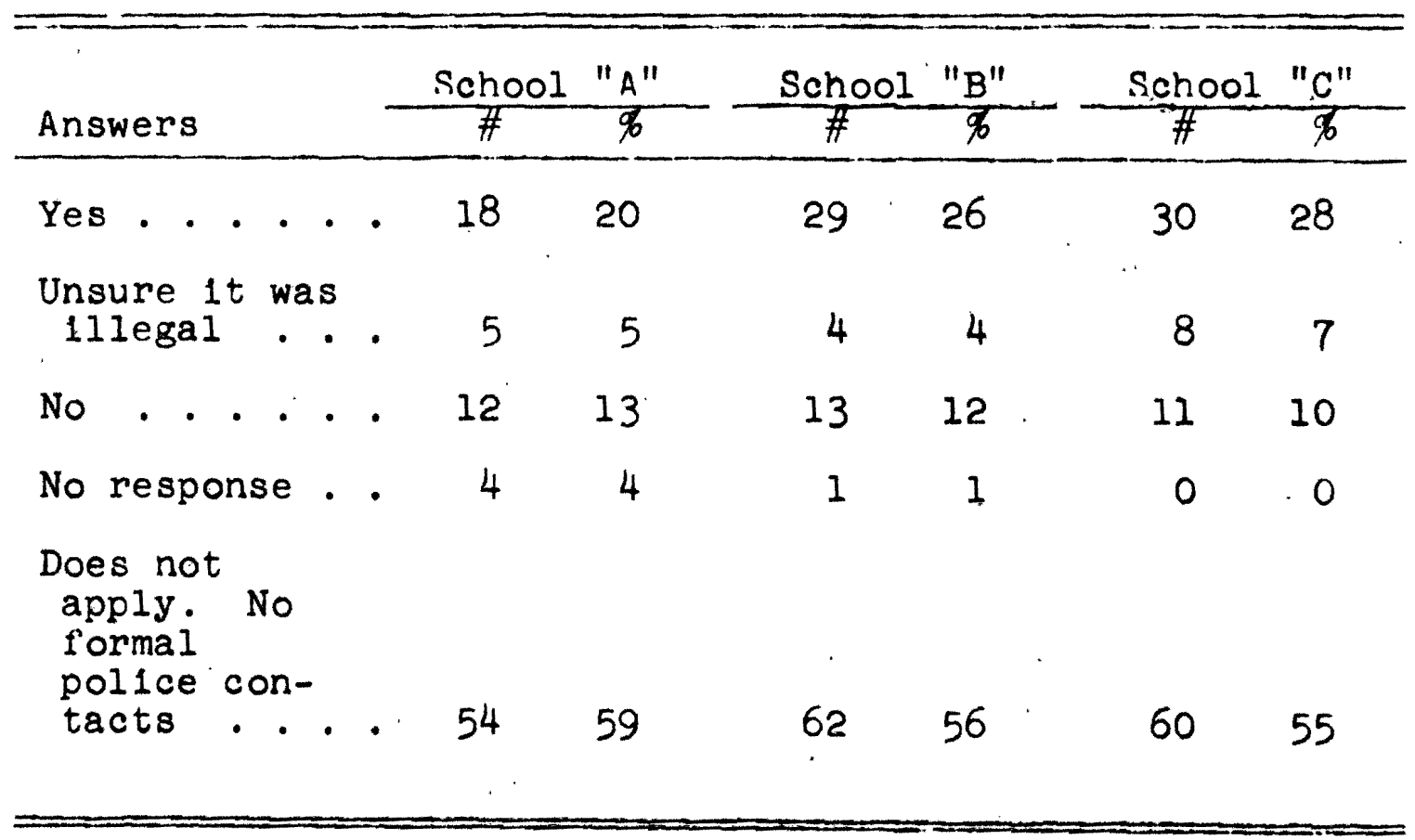

Of the students who had had formal pollce contact, most knew that their activity was 11 legal (20 per cent for school "A"; 26 per cent for school "B"; 28 per cent for school "C"). 
The students who did not know their activity was 11legal, or who were unsure that it was 1llegal, were asked to briefly explain what they had been doing. Responses were tallied and placed into general categories of "motor offenses" (speeding, improper use of a car, missing tall light, etc.), "status offenses" (curfew, running away from home, etc.), "pedestrian offenses" (hitchhiking, jaywalking) and "other" (trespassing, drugs, being stopped for questioning by police, witness to a crime, etc.).

Students from school "A" had most of their responses equally divided between the "motor offenses" and "other" categorles. Students from school "B" had most of their responses in "motor offenses." Students from school " $\mathrm{C}$ " had most of their responses in the "other" category. (See Table XXXIV, Appendix B.)

\section{Knowledge of Laws}

The trend towards similarity of response among the students that was found in the attitude section was continued in this section on laws. Students from school "B" continued to often show a higher percentage of correct answers but only by a very small margin. In fact, in this section, students from school " $B$ " often also had the largest 
percentage of incorrect answers. The trend shown in the attitude section, for students from school "C" to follow students from school " $B$ " was also not as consistent in this section on laws.

The law questions were designed to cover three areas: civil rights, general laws, and status offenses. The civil rights questions were well understood by the students, except trial by jury which the students did feel to be a right of Juveniles even though it is not. The general laws were well understood also, the law pertaining to the sale of marljuana being the most often missed. And finally, the question dealing with a status offense--a policeman detalning a juvenile for fallure to mind his parents--was missed by most students from all of the schools.

To conclude, the tables will be presented as such-first the three civil rights questions, then the general law questions, in the order of how well students responded. (This will hopefully give the reader a better appreciation for how well many teenagers do understand some laws and how other laws remain unclear to them.) And last, the status offense question and its response. The correct answer to the question has been placed in parentheses at the end of the question for the benefit of the reader. 
TABLE XX

WHEN STOPPED BY THE POLICE FOR A NONTRAFFIC OFFENSE, A JUVENILE IS REQUIRED TO GIVE

ONLY HIS NAME, AGE, AND ADDRESS (TRUE)

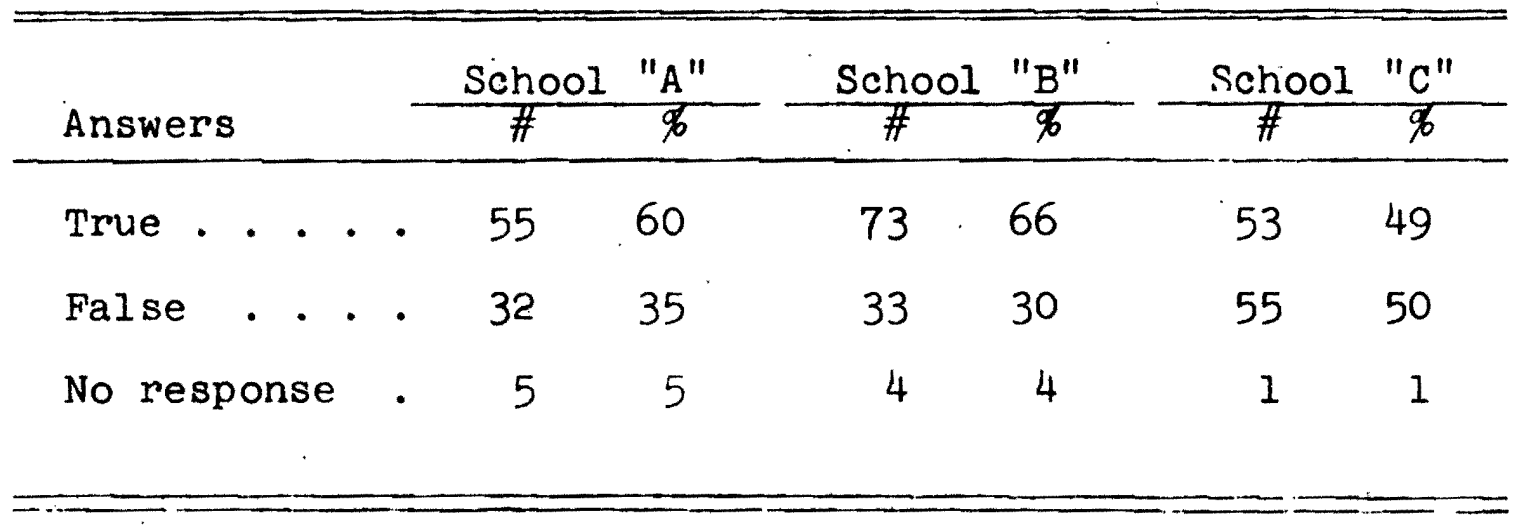

Here school "A" (60 per cent) and school "B" (66 per cent) had the highest percentage of their students responding correctly to the statement. Only 49 per cent of the students from school " $C$ ", responded correctly.

TABLE XXI

IF A JUVENIEE CANNOT AFFORD A IAWYER BUT HE REQUESTS TO HAVE ONE, THE COURT MUST APPOINT A LAWYER TO REPRESENT HIM (TRUE)

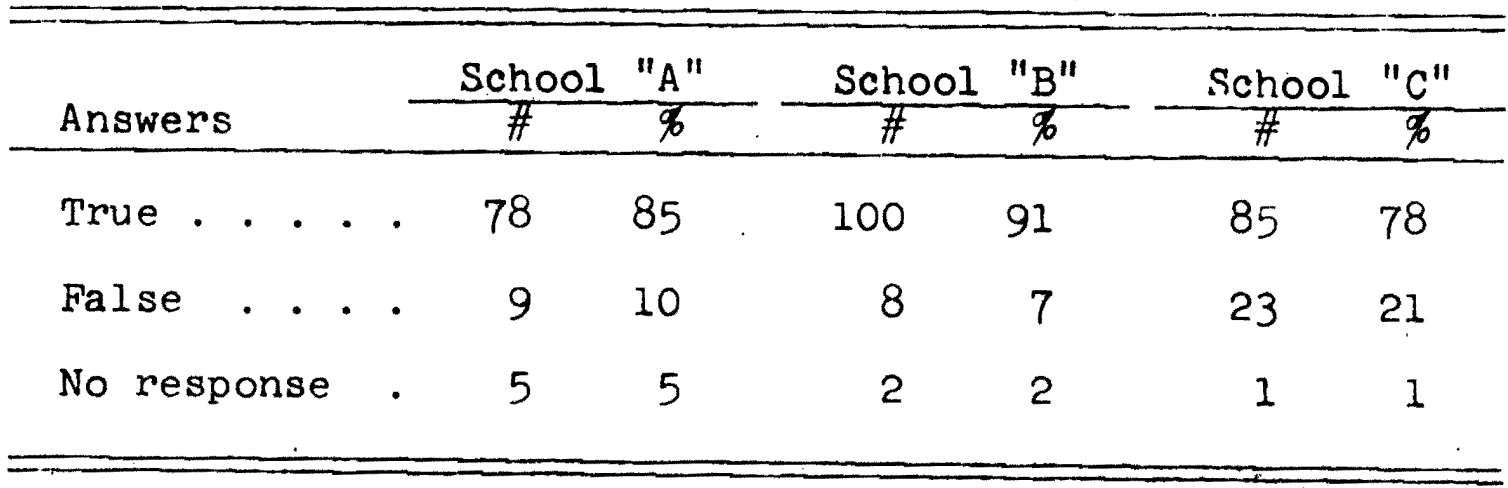


The students responded similarly to this statement with a majority of them showing an awareness of this civil right (85 per cent for school "A"; 91 per cent for school "B"; 78 per cent for school " $\mathrm{C}$ "). Students from school "B" exhibited the highest percentage correct and it was students from school "A" this time who were the closest follower-up In percentage correct.

TABLE XXII

A JUVENILE HAS THE RIGHT TO A JURY TRIAL (FALSE)

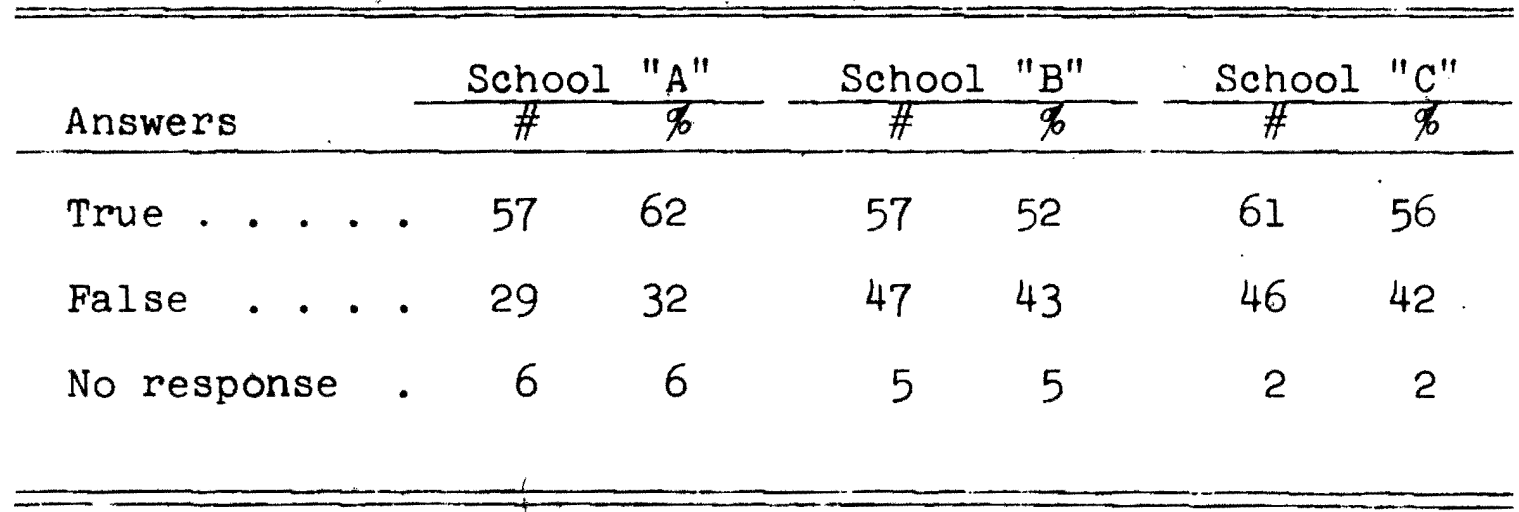

Here most of the students from each school responded Incorrectly (62 per cent for school "A"; 52 per cent for school "B"; 56 per cent for school " $C$ "). Students from school "B" (43 per cent) and school " $C$ " (42 per cent) had almost the same percentage who did answer correctly, while students from school "A" (32 per cent) fell considerably short of this percentage. 
TABLE XXIII

IT IS LEGAL TO DRINK ALCOHOLIC BEVERAGES

IN A MOVING CAR (FALSE)

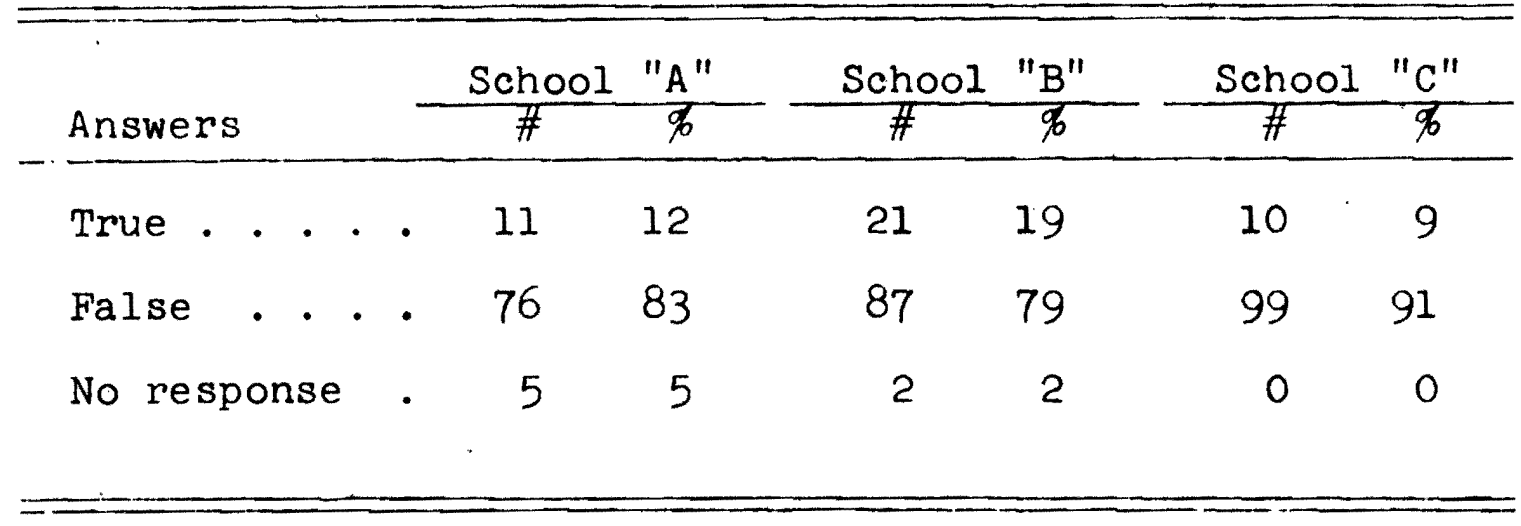

This law was the one best understood by the students from all the schools. Students from school "C" took the lead here, though, with the largest percentage ( 91 per cent) of correct answers. Conversely, students from school "B" lagged behind all the other schools here in the percentage of students answering correctly.

TABLE XXIV

THE CURFEW HOUR IN PORTLAND FOR 14-17 YEAR

OLDS ON FRIDAY AND SATURDAY NIGHTS IS 12:00 MIDNIGHT (TRUE)

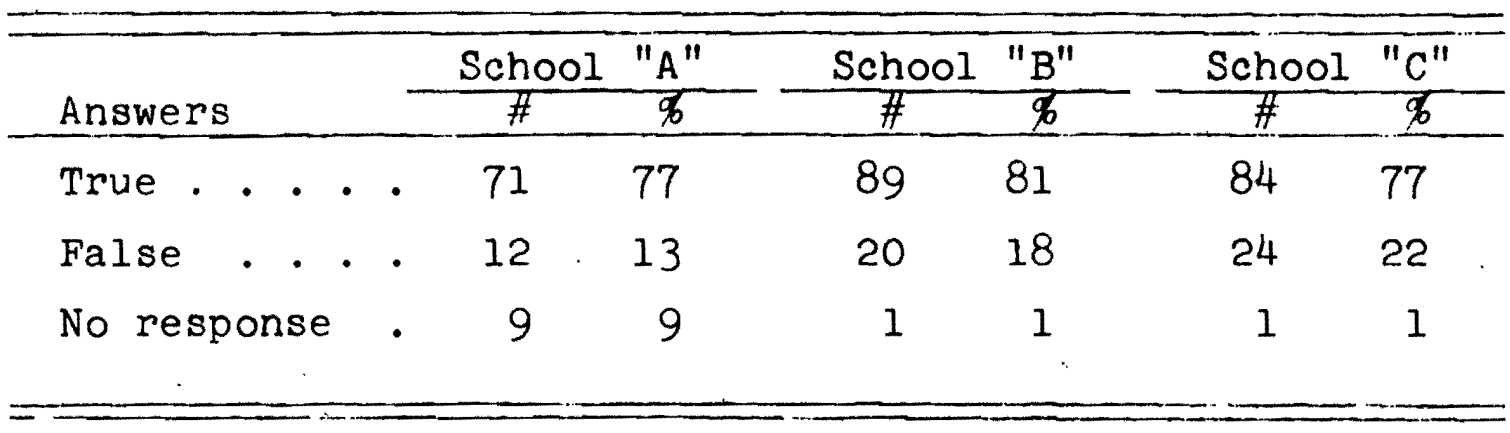


The curfew law appeared to be well understood by teenagers from all the schools. Students from school "B" regained their position as most correct respondent here ( 81 per cent) with students from schools "B" and "C" responding equally (77 per cent).

TABLE XXV

A JUVENILE IS GUILTY OF THE CRIME OF LOITERING

IF HE HANGS AROUND A SCHOOL BUILDING OR

GROUNDS WITHOUT HAVING A REASON FOR

BEING THERE (TRUE)

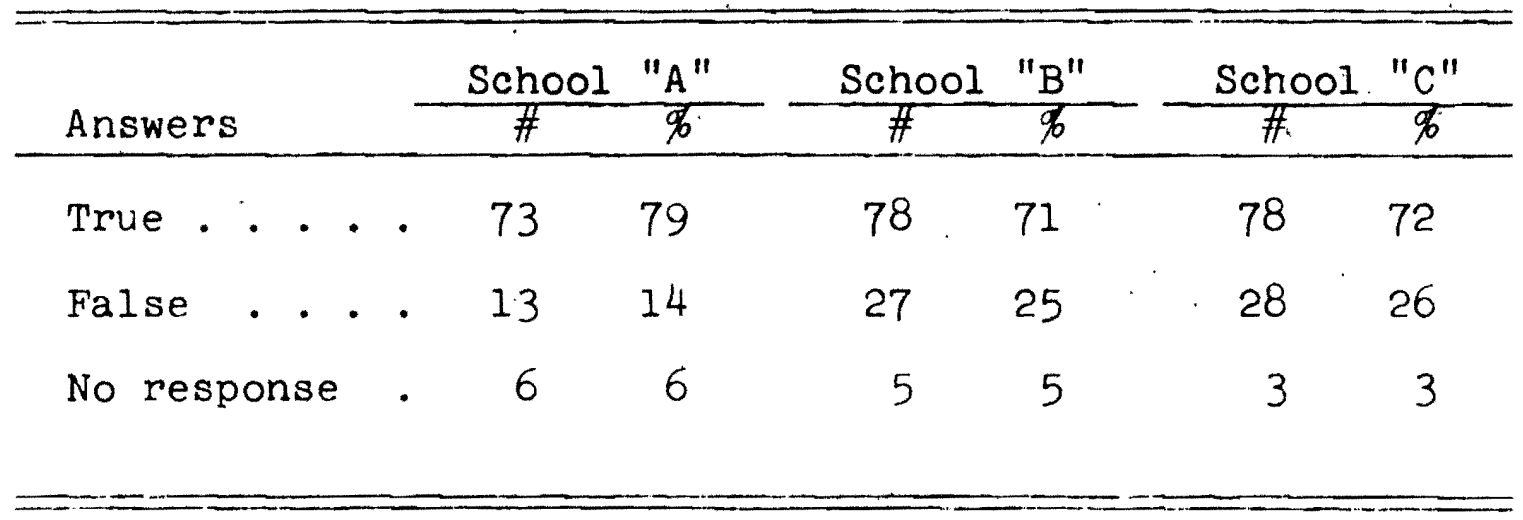

Students from school "A" had the highest correct response to this question (79 per cent). Students from schools "B" and " $C$ " were almost equal both in their percentage correct and incorrect. 
TABLE XXVI

IT IS LEGAL IN OREGON TO HITCHHIKE IF YOU ARE STANDING ON THE CURB OR OFF THE SHOULDER OF THE HIGHWAY (TRUE)

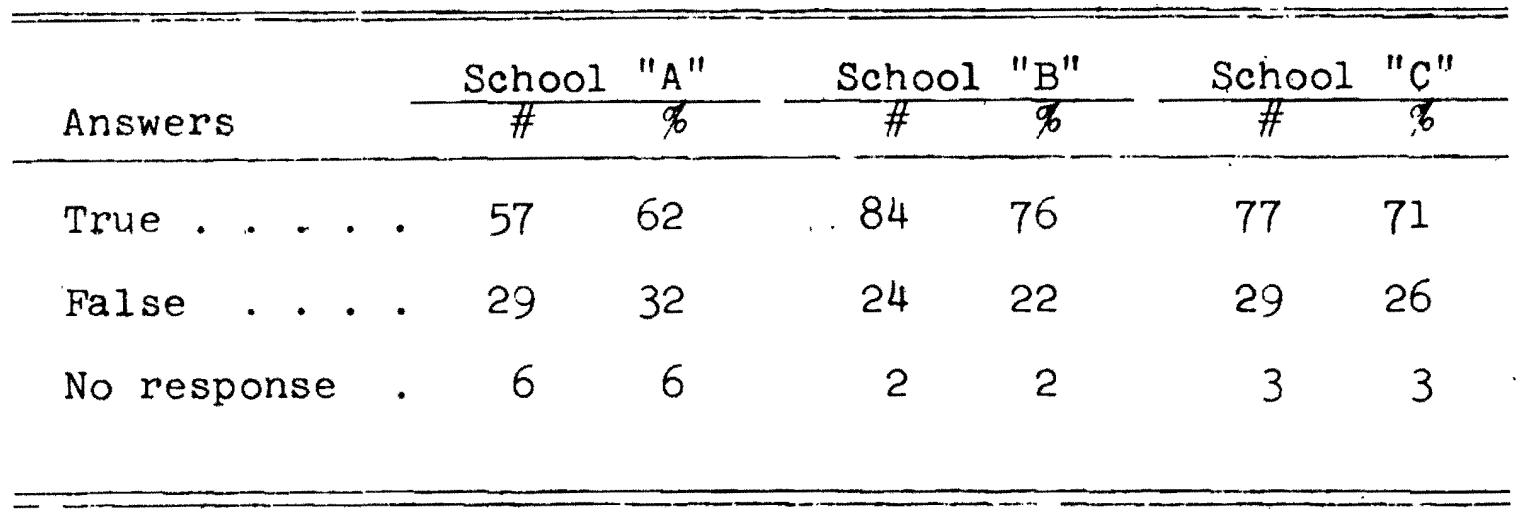

The students continued to exhibit an above average knowledge of laws as a substantial number of students from all the schools answered this question correctly (62 per cent for school "A"; 76 per cent for school "B"; 71 per cent for school "C").

TABLE XXVII

THE POLICE CAN STOP AND SEARCH THE INSIDE OF

A CAR WITHOUT A WARRANT IF THEY SUSPECT

THERE ARE DRUGS IN THE CAR (TRUE)

\begin{tabular}{|c|c|c|c|c|c|c|c|}
\hline \multirow[b]{2}{*}{ Answers } & \multirow{2}{*}{\multicolumn{3}{|c|}{$\frac{\text { School "A" }}{\#}$}} & \multicolumn{2}{|c|}{ School "B" } & \multirow{2}{*}{$\frac{\text { School }}{\#}$} & \multirow{2}{*}{ "c" } \\
\hline & & & $\%$ & \# & $\%$ & & \\
\hline True . . & • & 61 & 66 & 70 & 64 & 68 & 62 \\
\hline False & - & 25 & 27 & 35 & 32 & 41 & 38 \\
\hline No response & - & 6 & 7 & 5 & 5 & 0 & 0 \\
\hline
\end{tabular}


This law indicated a kind of police discretionary power that students seemed to be less aware of. Although close to 60 per cent of the students from all the schools did answer the question correctly, it was with less assurance--as indicated by the now larger percentage of students responding incorrectly (27 per cent for school "A"; 32 per cent for school "B"; 38 per cent for school "C").

TABLE XXVIII

IN OREGON, TO SELL MARIJUANA IS ONLY

A MISDEMEANOR IF IT IS LESS THAN

AN OUNCE (FALSE)

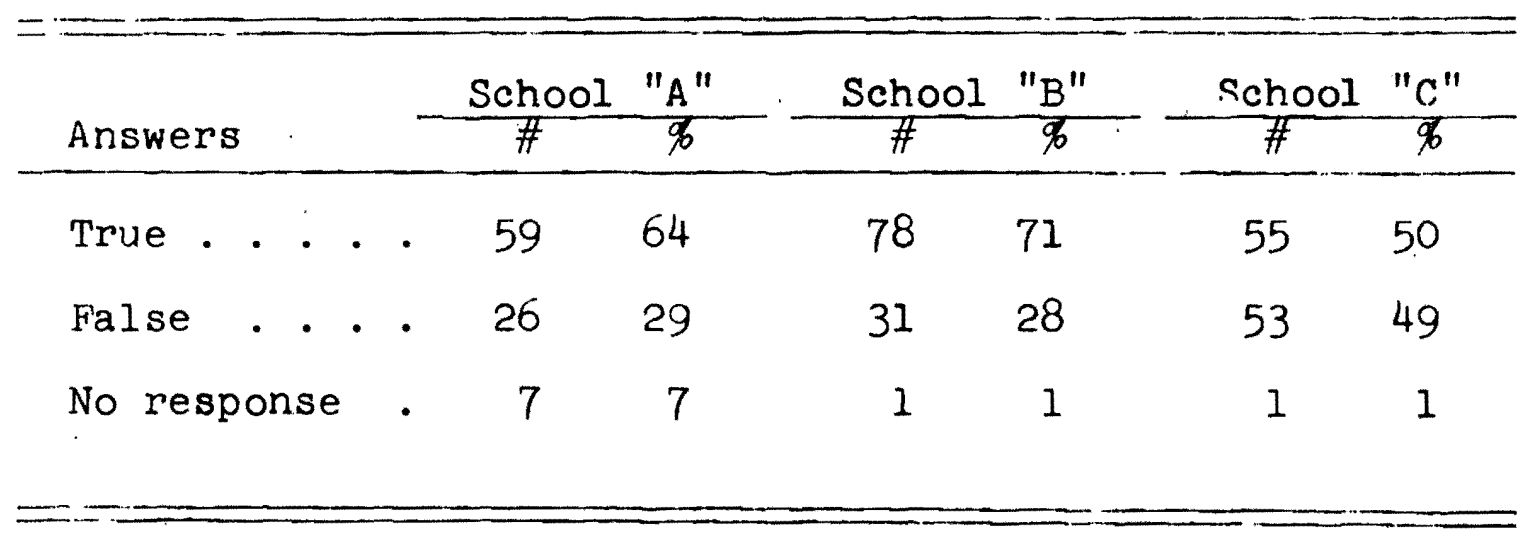

This law concerning the sale of marljuana turned out to be the least understood of all the laws. It should be noted here, though, that the students could have missed the "to sell" and read the question as "to possess"--wh1ch is in fact only a misdemeanor if less than an ounce. Students from school " $\mathrm{C}$ " had the largest correct response (49 per 
cent). Students from schools "A" (29 per cent) and "B" (28 per cent) had considerably lower correct responses.

TABLE XXIX

THE POLICE MAY DETAIN A JUVENILE FOR

FAILURE TO MIND HIS PARENTS (TRUE)

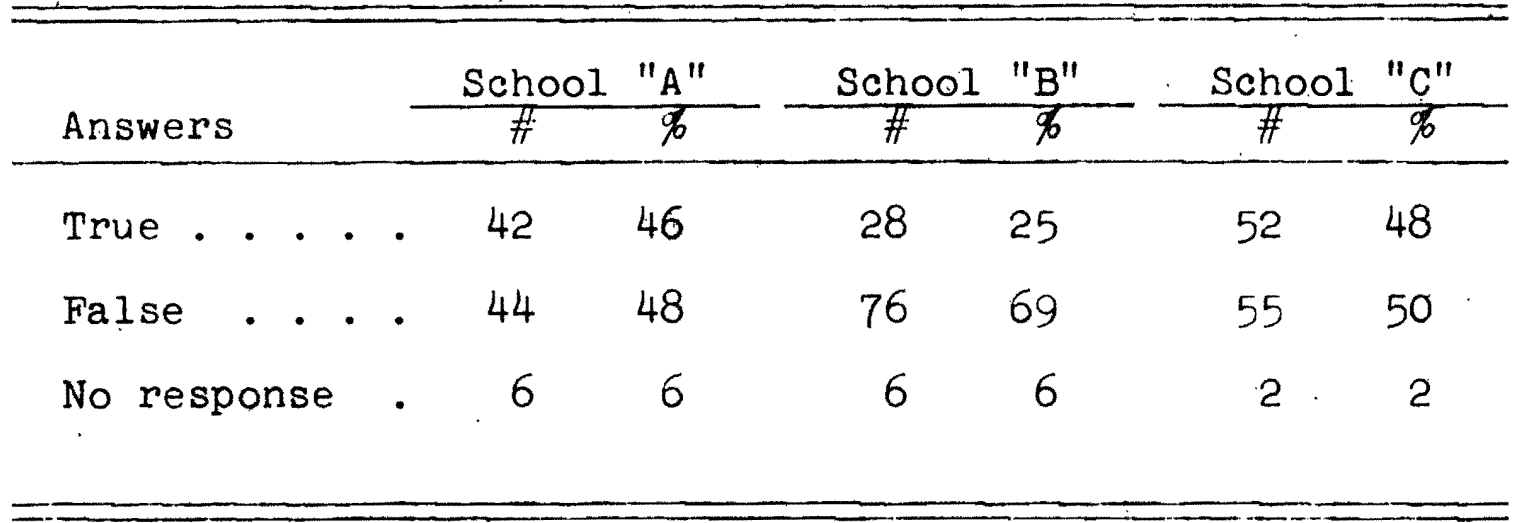

Again, a law which involved an extra amount of police discretion and power was not well understood by the students. This law applies only to juveniles--and so is a status offense--yet less than 50 per cent of the students from each school were aware that this is actually a law (46 per cent from school "A"; 25 per cent from school "B"; 48 per cent from school "C").

Students from school "B" had the lowest correct response to this question (25 per cent). Students from schools "A" and "C" were very close in their percentage of correct and incorrect responses. 


\section{Law Class--Knowledge of Laws}

Individual student scores from the knowledge of law section were determined (see Table XXXV, Append1X B) and a mean score for each school was computed. By comparing the mean score for those students who had taken a previous class in laws with the mean score for all students, it was shown that the students who had taken a course in laws did not do any better on the knowledge questions.

\section{TABLE XXX}

THE MEAN SCORE ON THE KNOWLEDGE OF LAW SECTION OF QUESTIONNAIRE

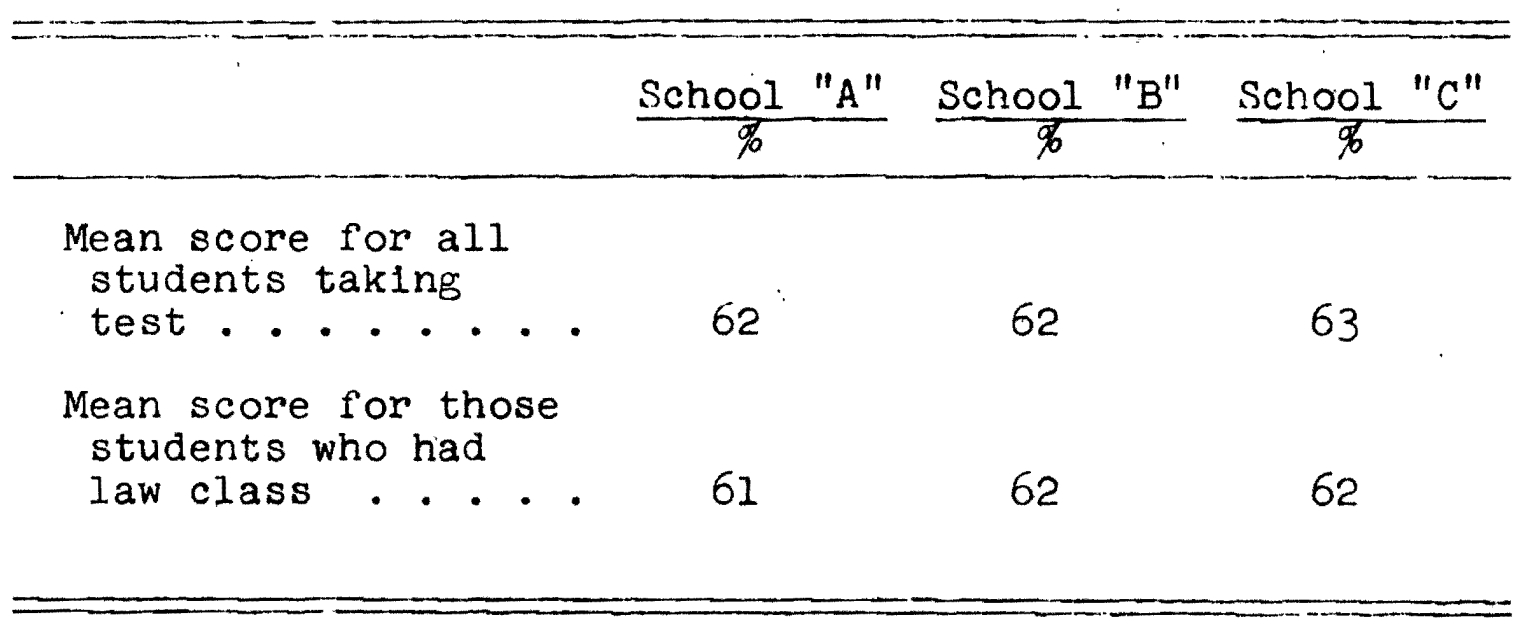


In fact, the mean score for those who took the class in laws and those who did not was the same percentage for students from school " $B$ " and even a very slightly lower percentage for those who took the class at schools "A" and "C."

Even though the students from school "B" were often slightly higher percentage-wise on the law questions, the school had a wide range of responses which of ten included the highest percentage incorrect, thus explaining why the mean for school "B" was similar to the mean for schools "A" and " $\mathrm{C} . "$

Law Class--Attitudes

The results in this section are very varied (see Tables XXXVI-XL, Append1X B). For school "A.", there were no conclusive results linking positive attitudes to a previous law class. In four out of five of the attitude questions, those students who had taken a previous class in law did respond with a larger percentage of favorable attitudes but they also responded with a larger percentage of unfavorable attitudes. (The last remaining attitude question was answered more positively by the students who had not taken a previous class in laws.) 
For school "B" there was more evidence to link the class and attitudes as three out of the five attitude questions were answered more positively and less negatively by students who had taken a previous class in laws. For the two remaining attitude questions, the students who had not taken a class in laws answered more positively. For school " $C$ " every one of the five attitude questions was answered more positively by students who had not taken a class in laws. 
CHAPTER IV

\section{CONCLUSIONS AND RECOMMENDATIONS}

Does a better understanding of the law create more favorable attitudes towards the law and 1ts enforcers? The answer would appear to be no, it does not. The findings of this study indicate that the students who had taken a previous class in laws or a law-related subject did not express more favorable attitudes towards the police than those students who had not taken a previous class in laws. The problem with this conclusion--and the reason why this researcher f'eels compelled to use "appears" to be no connection between an understanding of laws and attitudes--is that the students who had taken the previous class in laws also did not exhibit a better understanding of laws than those students without the class. Thus, the door is left open to the debate that since the students did not gain a better knowledge of laws, it is not a fair test of the theory which purports the existence of a relationship between a better understanding of laws and more favorable attltudes towards the law.

A second finding from this study, though, does offer some evidence against this theory. Students from school "B" who had taken a previous class in laws did not exhibit a 
better understanding of the law but they did express--in three out of five attitude questions--a more favorable att1tude towards the police. The implication of this result is that the previous class in law or law-related subjects helped to create more favorable attitudes without increasing the students' knowledge of laws. Conversely, students from school "C" who had taken a previous class in laws or lawrelated subjects answered five out of five of the attitude questions more negatively than those students who had not taken the class. Since these students from school "C" also did not exhibit a better or worse knowledge of laws than their fellow students without the class, the implication again is that the class can perhaps have an effect on the students' attitudes without affecting their understanding of laws.

This leads to two possible conclusions. First, that teaching laws to students simply isn't going to produce e1ther a better understanding of laws or a more favorable attltude concerning laws. Or, second, that there are other important variables--more important than increased knowledge--in the class which perhaps contribute to the creation of better, or even worse, attitudes (that 1t could be who teaches the class, or how it is taught, or what kinds of students take such a class, or what else is in the course in addition to the studying of laws. Here it is relevant 
to note that this researcher does not know the content of the law class or law-related classes which were taken by the students from the three high schools).

In this researcher's opinion, the second conclusion is the most valid, particularly if another qualification is added to the importance of classroom variables. - This qual1fication is a warning to educators that they must also be aware of the important variables outside the classroom--of the complexity of an attitude, how it is formed and how it is sustained. An attitude is a relationship between a person and a thing or object/person. Teachers can try to prepare the student part of this relationship to respond favorably to the objects and situations the student encounters, but unless the objects and situations respond favorably in reaction to the student, the attitude will modify or even diminish: ". . attitude change will disappear unless the environment is supportive of the behavioral change that accompanied the attitude change."12

The essence of this thought, then, is that the favorable attitudes created in the classroom can be negated by the unpleasant experience outside the classroom. A favorable attltude towards the police can be modified to an

\footnotetext{
12 Harry Triandis, Att1tude and Att1tude Change, p. 82.
} 
unfavorable attitude after an unpleasant or harassing experience with the police.

The first recommendation to be made, then, concerns a future study which educators should consider. This study would closely examine student attitudes towards the police both before and after a police contact, to see if, and to what degree, and in what direction, student attitudes change after a police contact.

This brings the situation to almost a full circle when it is noted that this was exactly what Dr. Portune, in his "Police-Juvenile Attitude Survey of 1965," found was the case for the adolescents in his study. In 1965, Dr. Portune theorlzed that the students did not have a sound enough understanding of laws to create an attitude towards the police that was favorable enough to withstand conflicting experiences with the police.

Because the relationship between attitudes and experLence has this circular effect, it remains difficult to decide not only at which point an intervention can be made, but also what this intervention should be, who should make 1t, and how effective can 1 t be. How early should soclety begin to try and form the relationship between its youth and outside authority? Is this just the parents' role, or do the schools and the police and the peer group have an equally important role? Should "attitude formation" classes 
be the method of intervention, should better police-juvenile relations be the intervention? And how effective can any intervention be $1 f$ what is learned in the classroom does not correspond to the experience outside the school?

Because the evidence is still not entirely in, the schools should be encouraged to continue this current experiment of offering classes in laws to the students. In all falrness to the schools, the program which was initiated in the fall of 1975 appears to have the organization and preparation which previous classes concerning laws perhaps did not have--thus the students will be recelving better classes. The second recommendation to be made, then, would be to encourage yet another study to be made a year from now after students have had the benefits of this more prepared curriculum. Th1s would be the better test of the theory that more knowledge creates better attitudes. But because there exists some evidence from this study which refutes that theory and which suggests that it is not the understanding of laws which is the important factor in attitude formation or change, a third recommendation is made that educators include other important variables in these law classes; 1.e., concentrate on the essential co-ordination between knowledge and experience in attitude formation and maintenance. The relationship between the police and the student is a major facilitator of this co-ordination. Bring 
police into the classroom to explain their role and mission to the students (here acceptance of the police by the student's peer group is of significance), and put students into patrol cars with an officer so they can empathize with the problems of the policeman's job. Continue to encourage the trend in law enforcement agencles towards creating speclallzed fuvenlle unlts, and even offer courses to pollce off1cers (and the community at large) in which an understanding of the problems of adolescence are emphasized. Former Superintendent of Chicago Police, O. W. Wilson, comments on this vital balance necessary between the attitudes of both parties to create a good relationship:

Public support and co-operation are influenced by the relationship between the public and their police, that is, 'by the actions and conduct of each other toward the other. The nature of any relationship is determined by the attitudes of the parties involved, because the actions of each are determined by their own attitude and conduct of the other. Each must have a correct attitude, therefore, if a desirable relationship is to be created and maintained.13

In addition to the central research question concerning the relationship between a better understanding of laws and the creation of more favorable attitudes, there are some other interesting findings from this study.

\footnotetext{
13 Richard Kobetz, The Police Role and Juvenile Delinquency, p. 183.
} 
Concerning the background and f'amily sttuation of the students who responded to the questionnaire, there are two results which should be noted. First is that al though three different socio-economic areas were represented by the students, there was very little evidence of this in any instances in which one might usually assume a higher or lower socio-economic background might matter. The percentage of students who were not currently living with both their natural parents was almost identical for all three schools. The percentage of students who had had a "few" (one to elght) casual contacts with the police, was almost identical f'or all three schools, and for all three schools this small number of casual contacts was the response of most of the students. The percentage of students who had been cited, detained, or picked up by the police was almost 1dentical for all three schools. In addition to all this, was the similarity of attitude response and knowledge of the laws among students from all three schools (although some evidence of socio-economic background, though inconclusive, might be present here since the students from the lowest socio-economic background did answer the attitude questions slightly less favorably than the students from the middle and highest socio-economic level. But the most favorable attitude responses were from the middle income students and not from the students from the highest economic level). 
This introduces another finding concerning student background, for although the prevalling thought in delinquency research is that single-parent families are potent breeding grounds for delinquency, the students from the school which expressed the most favorable attitudes, school "B," came from backgrounds in which 64 per cent of the families were headed by both the natural mother and father, but 36 per cent were not and of that 36 per cent, slightly over half were headed by a single parent. This is also true of school "C." The students from this school were slightly behind those from school " $B$ " in favorable att1tude responses and their families were also 67 per, cent headed by both the natural mother and father, but of the remaining 33 per cent, slightly over half were headed by a single parent. Only the students from school "A," who answered less favorably than students from the other two schools, came from backgrounds in which 63 per cent were headed by both natural parents, and of the remaining 37 per cent, half were headed by a twoparent, mother and step-father, combination.

Th1s again points out the complexities of attitude formation and how erroneous delinquency research can be when 1 t attempts to 1solate a single factor such as soc10economic background or marltal status of parents as the cause of bad attitudes and delinquent behavior. 
Concerning the attitudes expressed by the students-it has been ten years now since Dr. Portune's appeal to the schools to create better attitudes in their students, yet the conclusion of this study is that the students of today exhibit the same "nonnegative"14 attitude towards the police as they did in 1965. There were very few students who felt the police did an "excellent" fob. Rather, the students mostly gave the police a "good" rating on their job performance in enforcing laws and they were a little less positive in their evaluation of police performance in protecting people.

On the other hand, the students felt this protection of people was the most important police function over less positive and more hostile functions that were listed on the questionnaire for them to choose from. The students did generally feel that police do discriminate, but their choice of what the police discriminate against was not such prejudiclal things as "race" or "social class," but instead they chose options like "attitude towards the police," "age," and "appearance." Although differing on how weil the police perform their job, the students were very much in agreement in their bellef that police are necessary in

${ }^{14} \mathrm{Dr}$. Robert Portune, The Cincinnat1 Police-Juvenile Attitude Project, p. 10. 
society and that police recelve "a lot" of training before they are put on the force. The students also generally expressed a belief that being a policeman was a worthwhile profession yet it was not a profession the students felt they would choose as a career. The percentage of students responding that they had been "very unfairly" treated by the police in both casual and formal contacts was never over 10 per cent. Conversely, the "very fairly" response concerning police treatment in both casual and formal contacts was never over 27 per cent (except in one instance in which students from school "B" responded with 51 per cent to "very fa1r" treatment in casual contacts).

In considering the turmoll that this country has been through since Dr. Portune's study in 1965, there is some hope to be found in the continuation of at least a nonnegative attitude towards the police. For although job performance and police attitudes towards adolescents remain unsatisfactory in the eyes of the students (treatment during police contacts and police discrimination being two examples), there are some fundamentally positive aspects--such as police as protectors, pollce as necessary in our soclety, and pollce as well-trained--which offer a sound base from which to build more favorable attitudes.

Concerning the students' knowledge of laws, it has already been stated in "Results," Chapter III, that the 
students exhibited a very good understanding of their civil rights and of the laws which particularly pertain to them. The question which appeared to be least understood by the students was the one concerning a status offense (in this case, detention by an officer for fallure to mind parents). The status offense is a very volatile matter between police and adolescents. Complaints that teenagers volce against the police reveal that many adolescents are unaware of status offenses or do not consider them as laws. Hence, when their encounter with the police involves truancy from school, or a curfew violation, or running away from home and being out of parental control, they often feel the police are harassing them or over-extending their authority. A fourth recommendation will be made here--a recommendation that educators pay particular attention to the study and understanding of these status offenses in the classes about laws. Students should be fully acqualnted with the offenses and should have an opportunity to express their feelings about them, 1deally with a police officer in the classroom to respond to the feelings presented. 
In summary, the research question remains partially unanswered. The students who had taken a class in laws or law-related subjects did not exhlbit a better understanding of laws than other students, thus making it difficult to Judge whether a better understanding of laws can create more favorable attltudes towards the law and the enforcers of the law. However, the students from school " $B$ " who had taken a class in laws did express--in three out of flve attitude questions--a more favorable attitude without having a better score on the knowledge of law questions. And the students from school " $C$ " who had taken a class in laws did express-in five out of five attitude questions--a less favorable attitude without having a worse score on the knowledge of laws questions.

It would appear, then, that there are again two possible implications: (1) that classes in law have no effect on the students' attitudes; (2) that classes in law can have an effect (positive or negative) on student attitudes without having a corresponding effect on the students' knowledge of laws.

Assuming that educators will, and indeed should, continue the classes in law until another study can be made to elther dispute or corroborate these results, the second implication mentioned should be given particular attention. If Indeed classes in law do affect student attitudes without 
increasing their knowledge of the law, then future law classes should concentrate on attitude formation via the relationship between attitudes and experience. These classes should include as much coordinating materlal as possible--bring police into the classroom, put students into police stations and patrol cars, educate students and police about each other, and pay particular attention to such volatile matters as status offenses by trying to integrate student-police responses to these offenses in the classroom prior to a formal police contact. Underlying the entire issue, then, is the reminder that the reciprocity of a relationship is what enhances the creation and maintenance of favorable attitudes. 


\section{BIBLIOGRAPHY}

\section{BOOKS}

Coates, Robert, Ph.D. Dimensions of Police-Citizen Interaction: A Social Psychological Analysis. Michigan: Unversity M1crofilms, 1972 .

Earle, Howard. Student-Instructor Gulde on Police Community "Relations. Illinols: Charles Thomas Publisher, 1970.

Eldefonso, Edward. Law Enforcement and the Youthful Offender. New York: John Wlley and Sons, Inc., 1971.

, Alan Coffey and Walter Hartinger. Human Relations: Law Enforcement in a Changing Community. New Jersey: Prentice-Hall, Inc.

Fishbeim, Martin (ed.). Readings in Attitude Theory and Measurement. New York: John Wiley and Sons, Inc., 1967 .

Kenney, John, Ph.D., and Dan Pursult, M.S.S.A. Pollce Work With Juveniles and The Administration of Juvenile Justice. Illinols: Charles Thomas Publisher, 1970.

Kobetz, Richard. The Police Role and Juvenile Delinquency. Maryland: International Assoclation of Chiefs of Police, Inc., 1971.

Niederhoffer, Arthur and Alexander Smith. New Directions in: Police-Community Relations. San Francisco: Rinehart Press, 1974.

Pizzuto: Carmen. The Pollce Juvenile Unit: A Study in Role Consensus. Michigan: University Microfilms, Inc., 1968 .

Sher1f, Carolyn W. and Muzafer (eds.). Att1tude, EgoInvolvement, and Change. New York: John Wiley and Sons, Inc., 1967. 
Triandis, Harry C. Attitude and Att1tude Change. New York: John Wiley and Sons, Inc., 1971.

Voss, Harwin. Soclety, Delinquency, and Delinquent Behavior. Boston: LIttle, Brown and Company, 1970.

Wolfgang, Marvin. The Sociology of Crime and Delinquency.

New York: John Wiley and Sons, Inc., 1962.

$$
\text { REPORTS (FEDERAL GOVERNMENT AND LOCAL) }
$$

"The Cincinnati Police-Juvenile Attitude Project," an LEAA project report submitted to the Office of Law Enforcement Assistance, U.S. Department of Justice, 1968.

"Task Force Report: The Police," presented to The Pres1dent's Commission on Law Enforcement and Administration of Justice, Washington, D.C., Government Printing office, 1967.

"Clark County Youth Looks at the Law," prepared for the Health and Welfare Planning Council of Clark County, by Michael McCoy, 1968.

"1970 Census of Population and Housing," U.S. Department of Commerce, Bureau of Census.

"Youth Faces the Law," Metropolitan Youth Commission, 1974. NEWSPAPERS

The Oregonian, "Area Schools to Expand Law Studies," June $17,1975$. 


\section{APPENDIX A}


Students :

I am a Portland State graduate student at the School of Social Work. I am gathering information for a thesis on how teenagers feel about the pollce. I would appreclate your help in answering this questionnalre. Your answers will be strictly confidential.

Thank you

Barbara McCallum 
1. Are you male or female

2. What is your age?

3. Are you currently living with both your natural father and mother?

Yes

No

4. If the answer to No. 3 is "no," with whom are you currently living?

Mother only

Father only

Other (please specify)
Mother and step-father

Father and step-mother

5. What is the yearly income level of your family?

$$
\begin{array}{ll}
\text { Under } \$ 5,000 & \$ 10,000-\$ 15,000 \\
\$ 5,000-\$ 10,000 & \$ 15,000-\text { above }
\end{array}
$$

6. Have you ever taken a class in school devoted entirely to teaching you about laws or law-related subjects like civil rights?

Yes No 
1. Do you think it is necessary to have pollce in our soclety?

Yes Only in some instances___ No

2. What is the most important function of the police? (Check one.)

Catching criminals

Enforcing laws

Punishing lawbreakers

Maintaining order

Protecting people and property

3. How well do you think the police do their job of enforcling laws?

Excellent Good Fa1r

Poor

4. How well do you think the police do thelr job of protecting people?

Excellent Good Fair Poor

5. Do you think the police treat everyone the same? Yes Sometimes No

6. If the answer to No. 5 is "sometimes" or "no," check the two things the police most discriminate agalnst:

Age - Race - Att1tude towards the pollce -
Sex Appearance Social Class -

7. Do you think that being a policeman is a worthwhile profession?

Yes Unsure No

8. Do you think that police in general understand adolescents?

Yes Somewhat No 
9. How much special police training do you think police recelve before they are put on the force?
A lot
Some
A little
None

10. Have you ever consldered a career as a policeman or pollcewoman?

Yes and still do No and still don't

Yes but now don't Never thought of it before

11. How many casual contacts (nonarrest sltuations like asking directions, reporting a theft, talking to a policeman on patrol) have you had with police?
Many (over 15)
Moderate $(8-15)$
Few $(1-8)$ None

12. In these casual contacts with the police, how have you been treated?
Very fairly Fairly
Unfairly Very unfairly

13. Have you ever been picked up, cited, detained, or arrested by the police?

Yes

No

14. If you answered "yes" to No. 13, please answer the following questions:

a. How many of these formal contacts have you had with the police?

Many (over 15) Moderate $(8-15)$ Few $(1-8)$

b. How were you treated by the police during these formal contacts?

Very fairly Falrly Unfa1rly Very unfairly 
c. Were you involved in an activity you knew to be 11legal (speeding, drinking under age, etc.) when you had formal contact with police?

Yes Unsure it was 111 egal No

d. If your answer to " $c$ " was "unsure" or "no;" please brlefly explain why you were detalned by the pollce: 
The following questions deal with your knowledge of the laws that concern you. The term "Juvenile" w1ll be used as the questions are taken from the actual wording of the laws dealing. With persons under the age of 18 who live in the state of oregon.

1. When stopped by the police for a nontraffic offense, a Juvenile is required to give only his name, age, and address.

True

False

2. If a juvenile cannot afford a lawyer but he requests to have one, the court must appoint a lawyer to represent him.

True False

3. A Juvenile has the right to a jury trial.

True False

4. The curfew hour in Portland for 14-17 year olds on Friday and Saturday nights is 12:00 midnight.

True

False

5. It is legal in Oregon to hitchhike if you are standing on the curb or off the shoulder of the highway.

True

False

6. In Oregon, to sell marijuana is only a misdemeanor if it is less than an ounce.

True

False

7. The police can stop and search the inside of a car without a warrant if they suspect there are drugs in the car.

True

False 
8. A juvenile is guilty of the crime of loltering if he hangs around a school bullding or grounds without having a reason for being there.

True

False

9. It is legal to drink alcoholic beverages in a moving car.

True _ False

10. The police may detain a juvenile for fallure to mind his parents.

True

False 
APPENDIX B 
TABLE XXXI

ARE YOU MALE OR FEMALE?

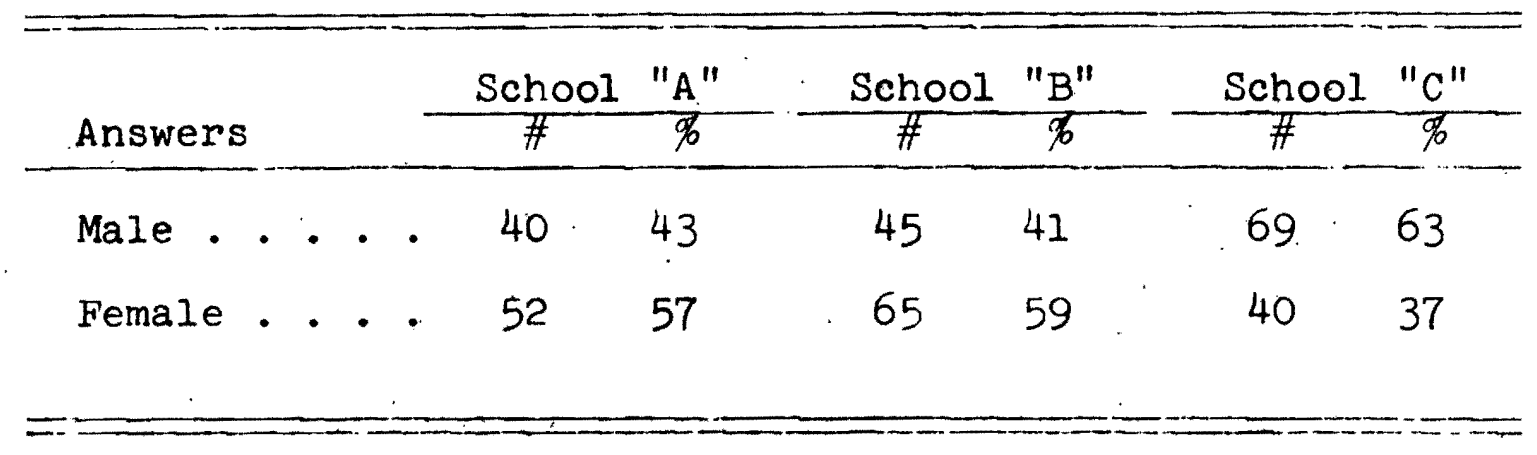

TABLE XXXII

WHAT IS YOUR AGE?

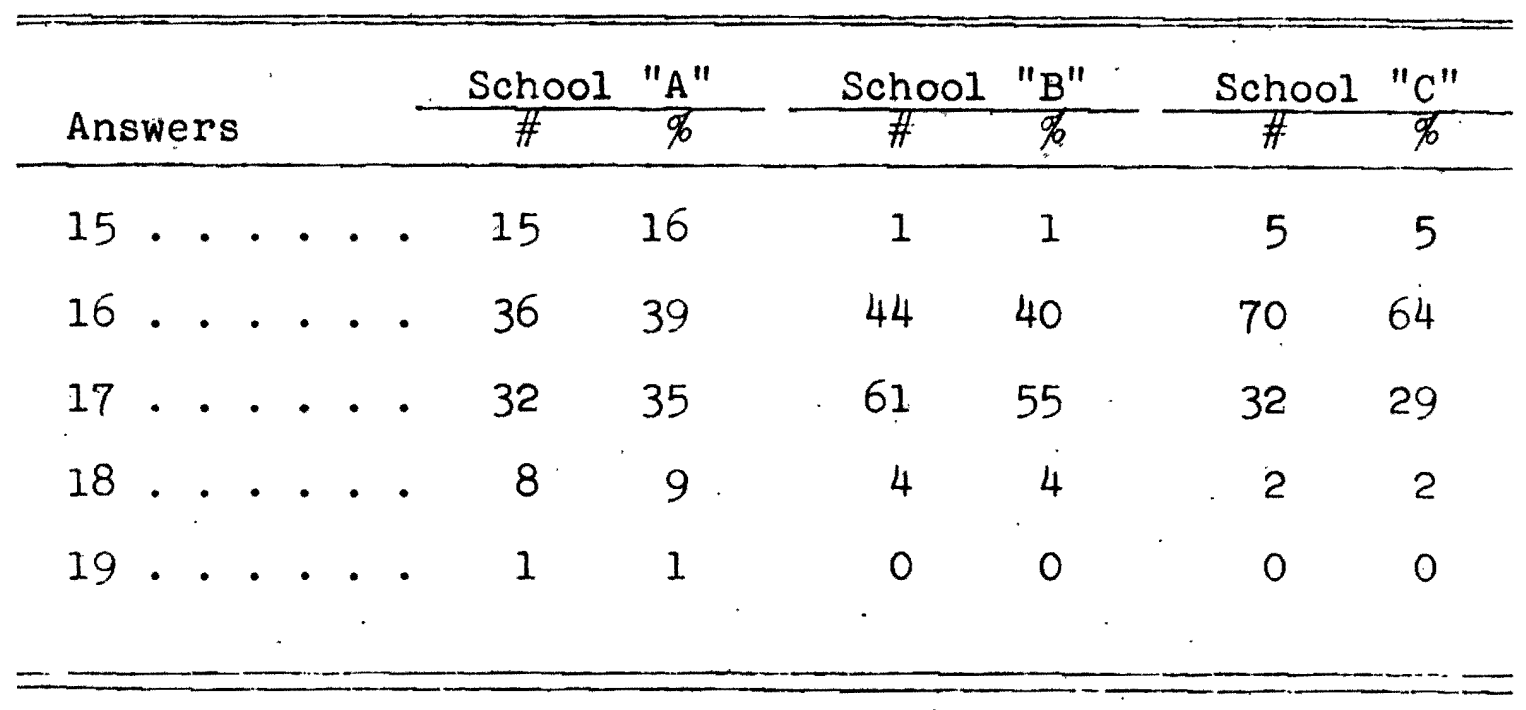


TABLE XXXIII

HAVE YOU. EVER CONSIDERED A CAREER AS A POLICEMAN OR POLICEWOMAN?

\begin{tabular}{|c|c|c|c|c|c|c|c|}
\hline & & School & "A". & School & "B" & School & "C" \\
\hline Answers & & $\#$ & & $\#$ & $\%$ & $\#$ & Po \\
\hline $\begin{array}{l}\text { Yes and } \\
\text { stili do. }\end{array}$ & . & 15 & 16 & 15 & 14 & 15 & 14 \\
\hline $\begin{array}{l}\text { Yes but } \\
\text { now don't }\end{array}$ & • & 14 & 15 & 32 & 29 & 26 & 24 \\
\hline $\begin{array}{l}\text { No and } \\
\text { st111 } \\
\text { don't }\end{array}$ & & 42 & 46 & 37 & 34 & 40 & 37 \\
\hline $\begin{array}{l}\text { Never thoug } \\
\text { of it } \\
\text { before. }\end{array}$ & & 19 & 21 & 24 & 22 & 28 & 26 \\
\hline No response & 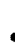 & 2 & 2 & 2 & 2 & 0 & 0 \\
\hline
\end{tabular}


TABLE XXXIV

IF YOU DID NOT KNOW YOU WERE INVOLVED IN AN ACTIVITY THAT WAS ILLEGAL WHEN YOU HAD FORMAL CONTACT WITH THE POLICE, COULD YOU BRIEFLY EXPLAIN WHY YOU WERE DETAINED

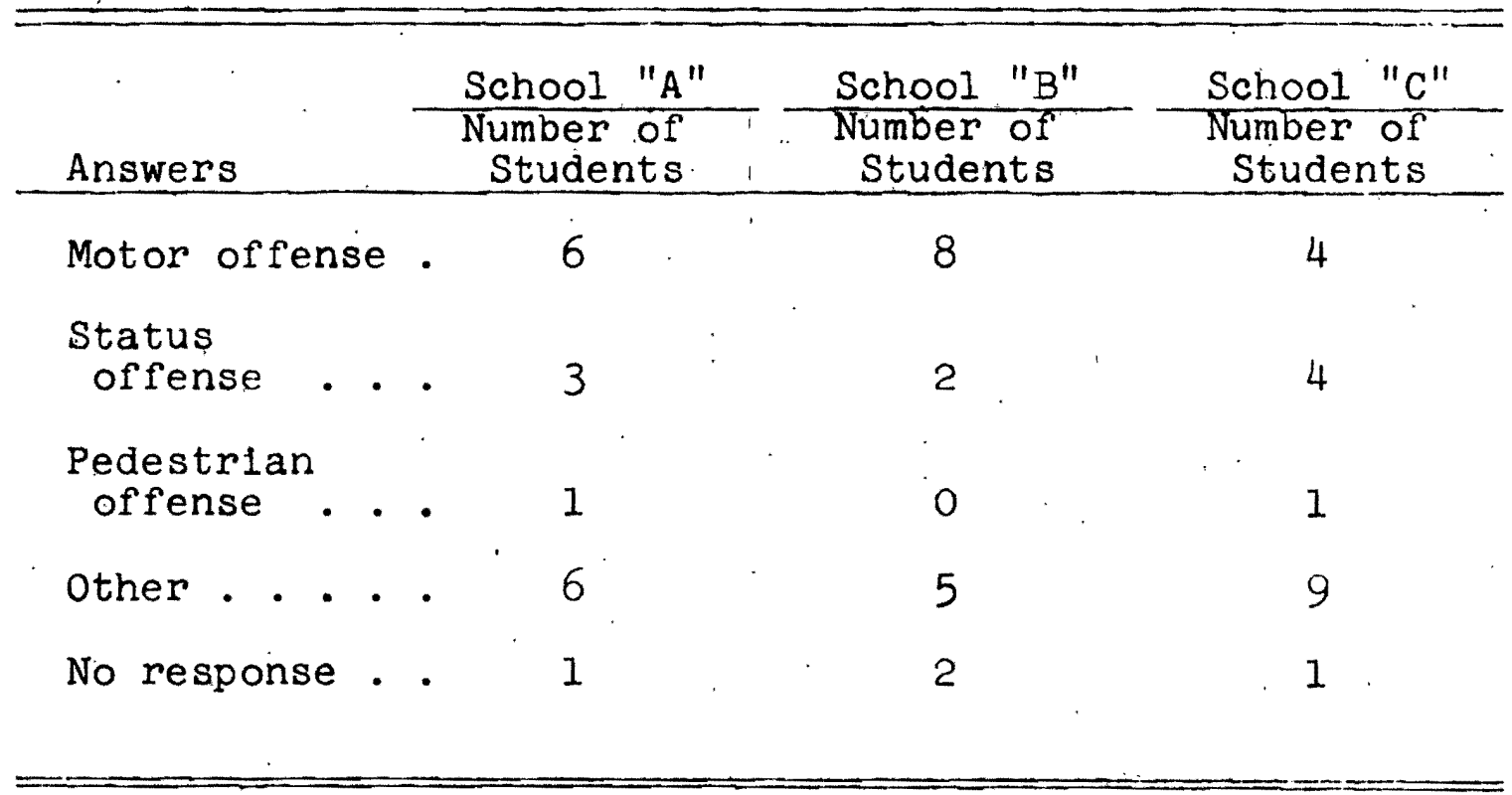


TABLE XXXV

INDIVIDUAL STUDENT SCORES ON

KNOWLEDGE OF IJAW QUESTIONS

\begin{tabular}{|c|c|c|c|}
\hline $\begin{array}{l}\text { Per cent } \\
\text { correct }\end{array}$ & $\begin{array}{l}\text { School "A" } \\
\text { Number of } \\
\text { Students }\end{array}$ & $\begin{array}{l}\text { School "B" } \\
\text { Number of } \\
\text { Students }\end{array}$ & $\begin{array}{l}\text { School "C" } \\
\text { Number of } \\
\text { Students }\end{array}$ \\
\hline 0 & 4 & 1 & 0 \\
\hline 10 & 1 & 0 & 0 \\
\hline 20 & 1 & 0 & 0 \\
\hline 30 & 1 & 1 & 4 \\
\hline 40 & 4 & 15 & 7 \\
\hline 50 & 17 & 16 & 23 \\
\hline 60 & 23 & 28 & 20 \\
\hline 70 & 15 & 27 & 27 \\
\hline 80 & 17 & 12 & 23 \\
\hline 90 & 8 & 9 & 3 \\
\hline 100 & $i$ & 1 & 2 \\
\hline $\begin{array}{l}\text { Total number } \\
\text { of students }\end{array}$ & 92 & 110 & 109 \\
\hline
\end{tabular}


TABLF XXXVI

HOW WELL DO YOU THINK THE POLICE DO THEIR JOB OF ENFORCING LAWS?

\begin{tabular}{|c|c|c|c|c|c|c|c|}
\hline \multirow{2}{*}{\multicolumn{2}{|c|}{ School "A" }} & \multirow[b]{3}{*}{$\dot{.}}$. & \multicolumn{2}{|c|}{$\begin{array}{l}\text { Students who } \\
\text { took law class } \\
\frac{\#}{\not 6}\end{array}$} & \multicolumn{2}{|c|}{$\begin{array}{l}\text { Students with- } \\
\text { out law class }\end{array}$} & $\begin{array}{l}\text { Total number } \\
\text { of students }\end{array}$ \\
\hline & & & & & & & . \\
\hline $\begin{array}{l}\text { Excelle } \\
\text { Good } \\
\text { Falr: } \\
\text { Poor } \\
\text { No resp }\end{array}$ & $\begin{array}{l}\text { nt } \\
\cdot \dot{0} \\
\dot{0} \\
\dot{0} \cdot\end{array}$ & & $\begin{array}{r}1 \\
10 \\
8 \\
4 \\
0\end{array}$ & $\begin{array}{r}4 \\
43 \\
35 \\
17 \\
0\end{array}$ & $\begin{array}{r}1 \\
26 \\
38 \\
3 \\
1\end{array}$ & $\begin{array}{r}1 \\
39 \\
54 \\
4 \\
1\end{array}$ & $\begin{array}{r}2 \\
36 \\
46 \\
7 \\
1\end{array}$ \\
\hline Totals & - & - & 23 & & 69 & & 92 \\
\hline School & "B" & & & & . & & \\
\hline $\begin{array}{l}\text { Excellet } \\
\text { Good : } \\
\text { Fair: } \\
\text { Poor : } \\
\text { No resp }\end{array}$ & $\begin{array}{l}\text { nt } \\
\dot{0} \cdot \dot{ } \\
\dot{0} \dot{\text { ons }}\end{array}$ & $\begin{array}{l}. \\
. \\
.\end{array}$ & $\begin{array}{r}6 \\
35 \\
15 \\
2 \\
1\end{array}$ & $\begin{array}{r}10 \\
59 \\
25 \\
3 \\
2\end{array}$ & $\begin{array}{r}1 \\
31 \\
16 \\
2 \\
1\end{array}$ & $\begin{array}{r}2 \\
61 \\
31 \\
4 \\
2\end{array}$ & $\begin{array}{r}7 \\
66 \\
31 \\
4 \\
2\end{array}$ \\
\hline Totals & .. & $\bullet$ & 59 & & 51 & & 110 \\
\hline School & "C" & & & & & & \\
\hline $\begin{array}{l}\text { Excellel } \\
\text { Good } \\
\text { Fair } \\
\text { Poor. } \\
\text { No resp }\end{array}$ & 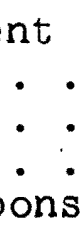 & $\begin{array}{l}\cdot \\
\cdot \\
\cdot \\
\cdot \\
\cdot\end{array}$ & $\begin{array}{l}0 \\
7 \\
7 \\
1 \\
1\end{array}$ & $\begin{array}{r}0 \\
44 \\
44 \\
6 \\
6\end{array}$ & $\begin{array}{r}5 \\
51 \\
30 \\
6 \\
1\end{array}$ & $\begin{array}{r}5 \\
55 \\
32 \\
6 \\
1\end{array}$ & $\begin{array}{r}5 \\
58 \\
37 \\
7 \\
2\end{array}$ \\
\hline Totals & . . & & 16 & & 93 & & 109 \\
\hline
\end{tabular}


TABLE XXXVII

HOW WELL DO YOU THINK THE POLICE DO THEIR JOB OF PROTECTING PEOPLE?

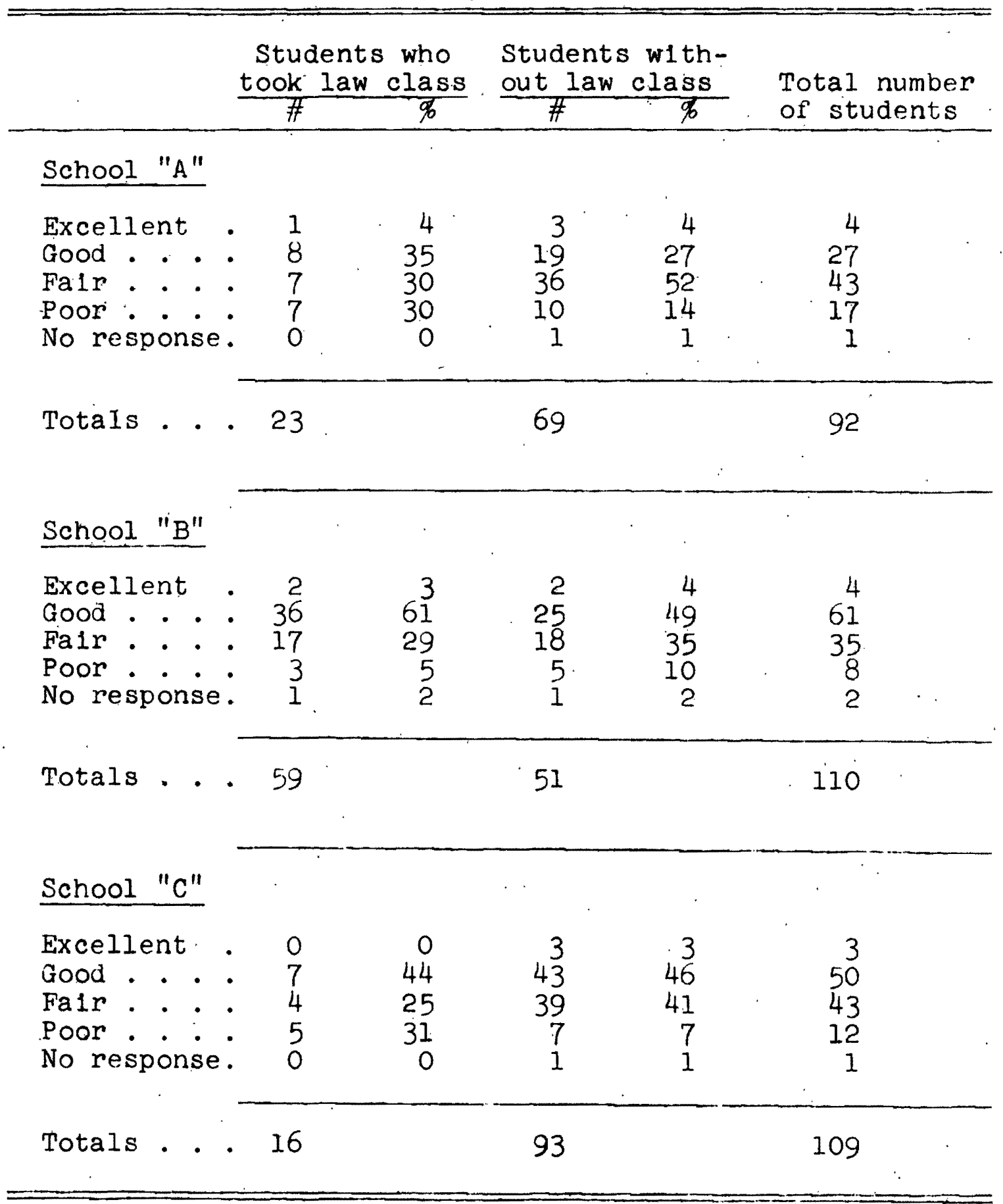


TABLE XXXVIII

IS BEING A POLICEMAN A WORTHWHILE PROFESSION?

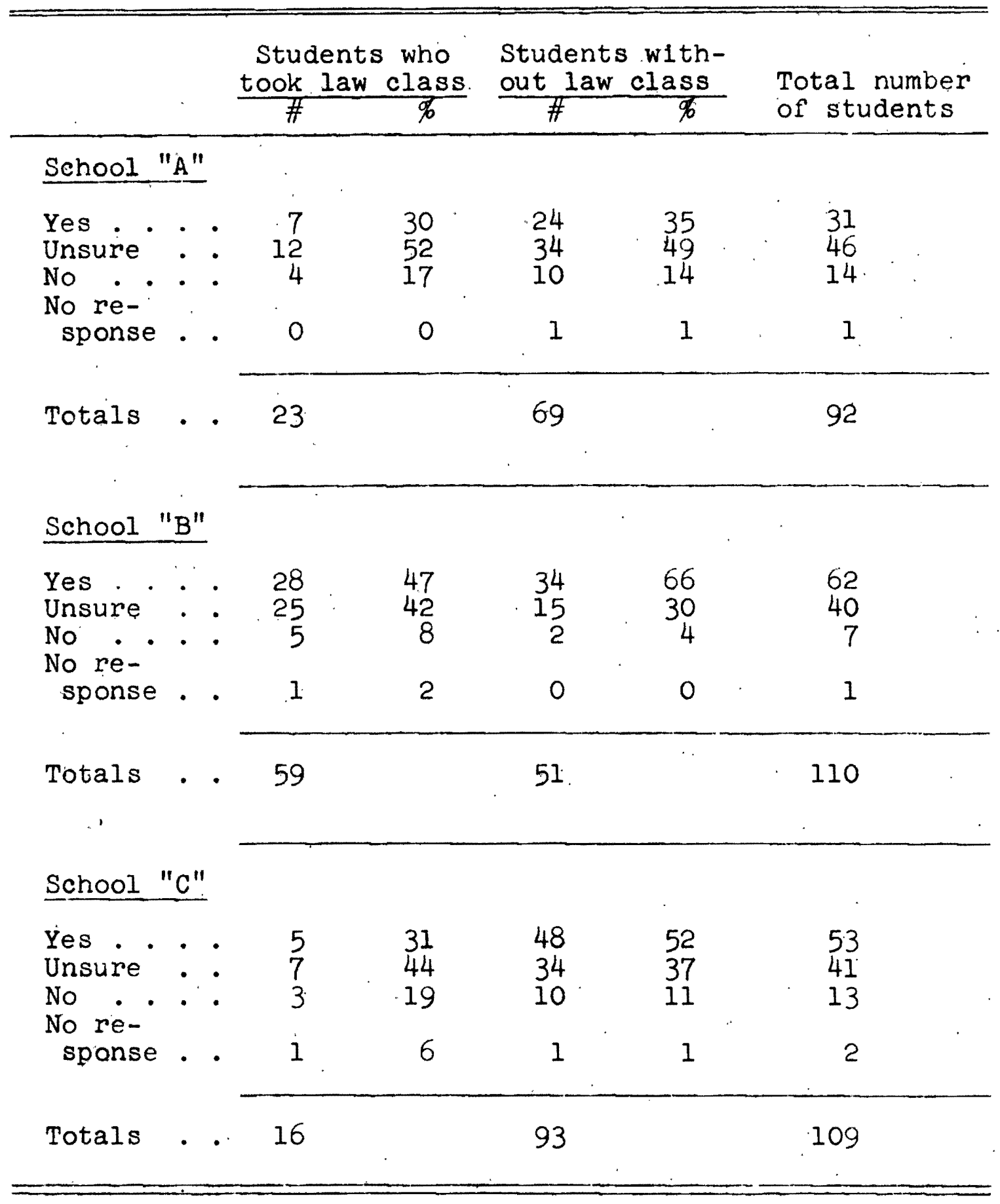


TABLE XXXIX

IN YOUR CASUAL CONTACTS WITH THE POLICE, HOW WERE YOU TREATED?

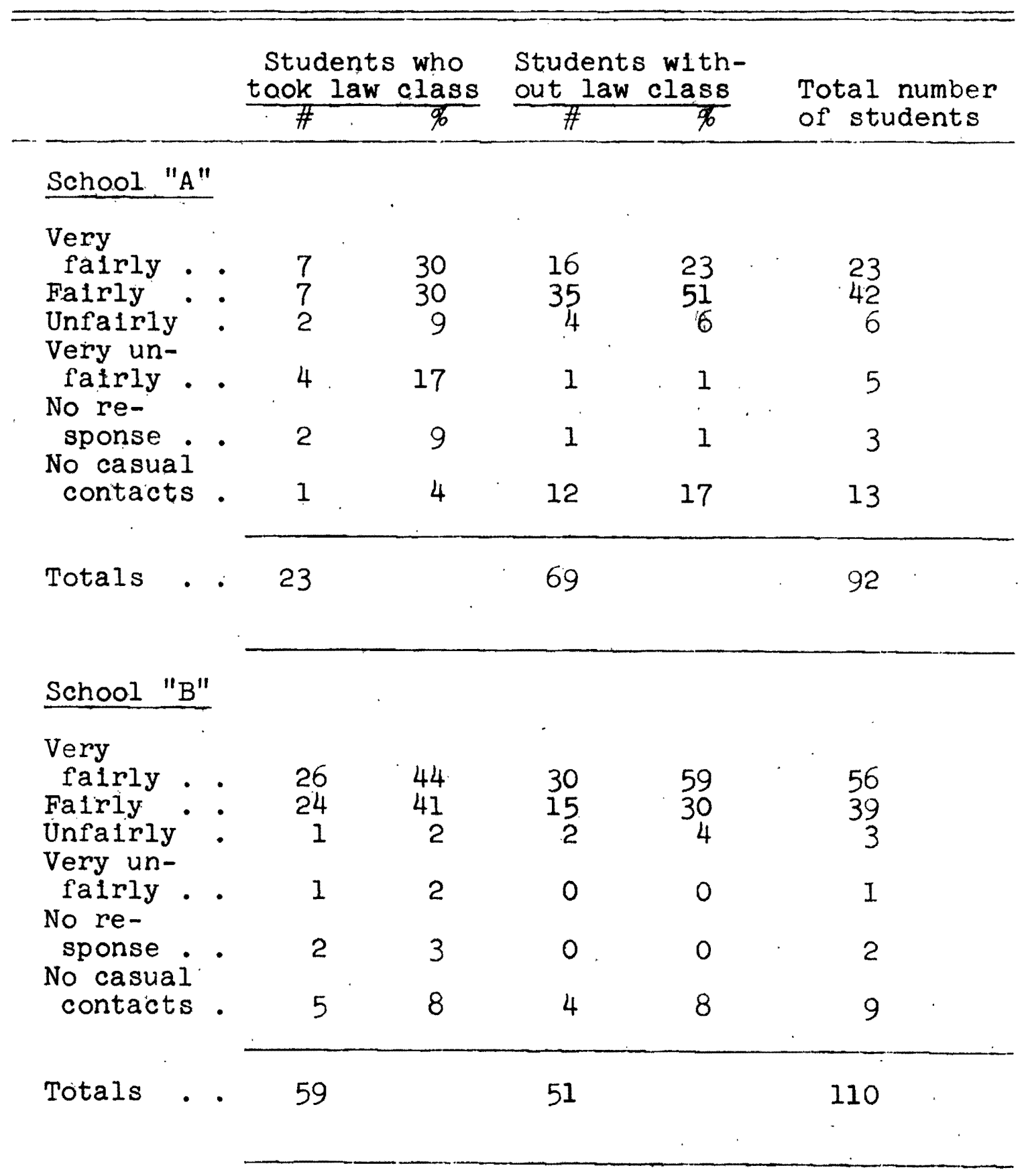


TABLE XXXIX--Cont1nued

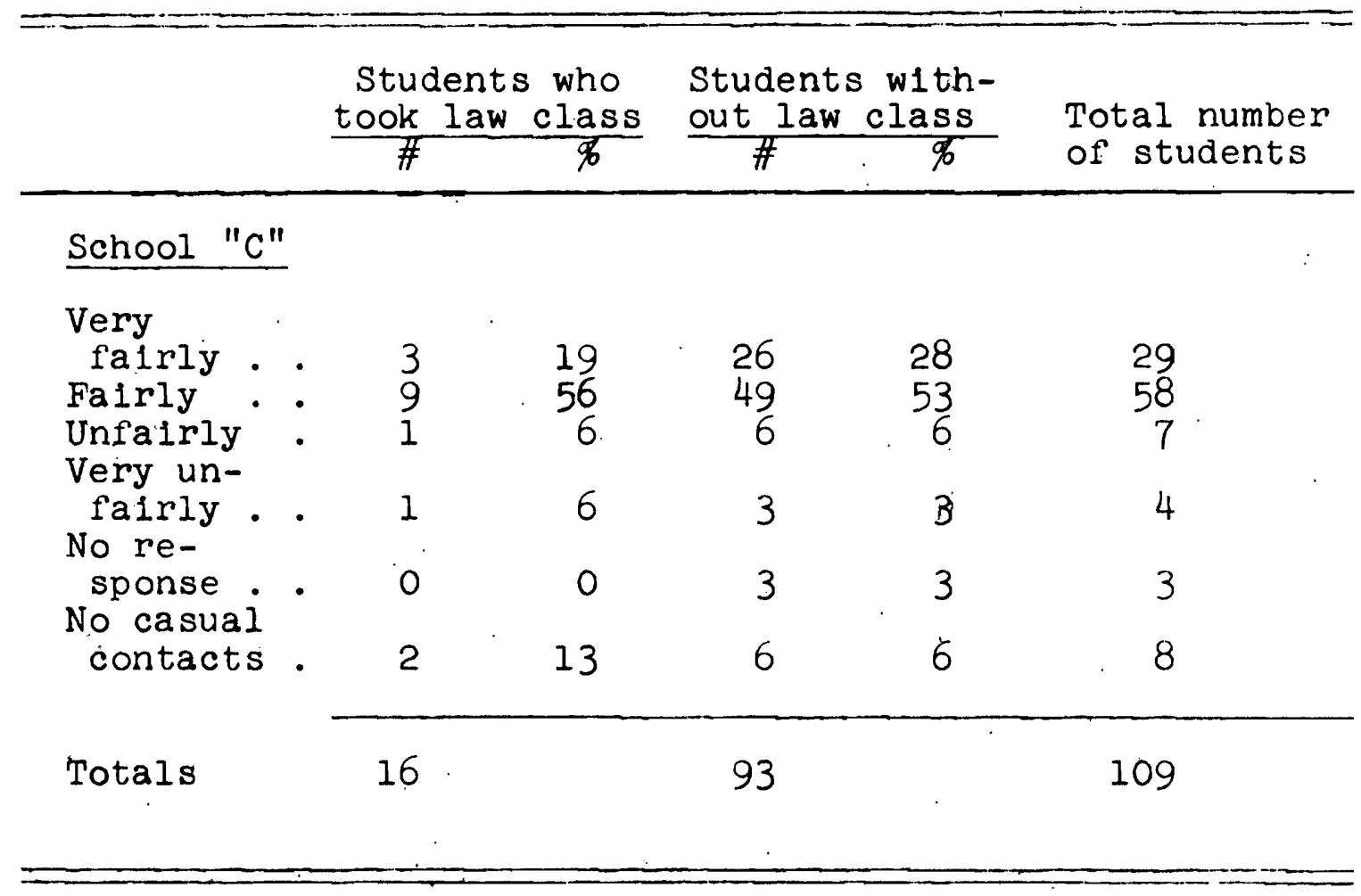


TABLE XL

IN YOUR FORMAL CONTACTS WITH THE POLICE, HOW WERE YOU TREATED?

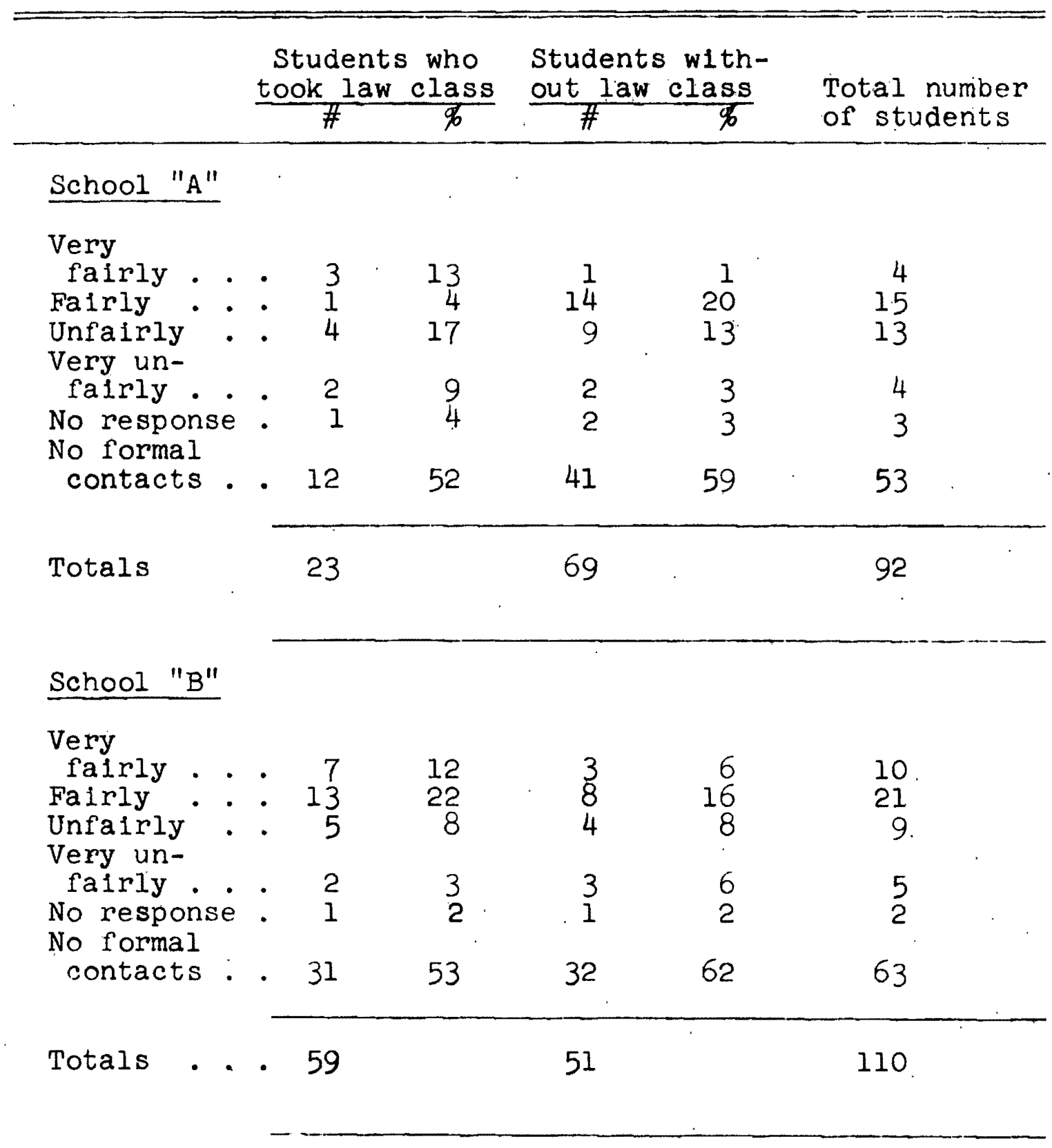


TABLE XI--Cont1nued

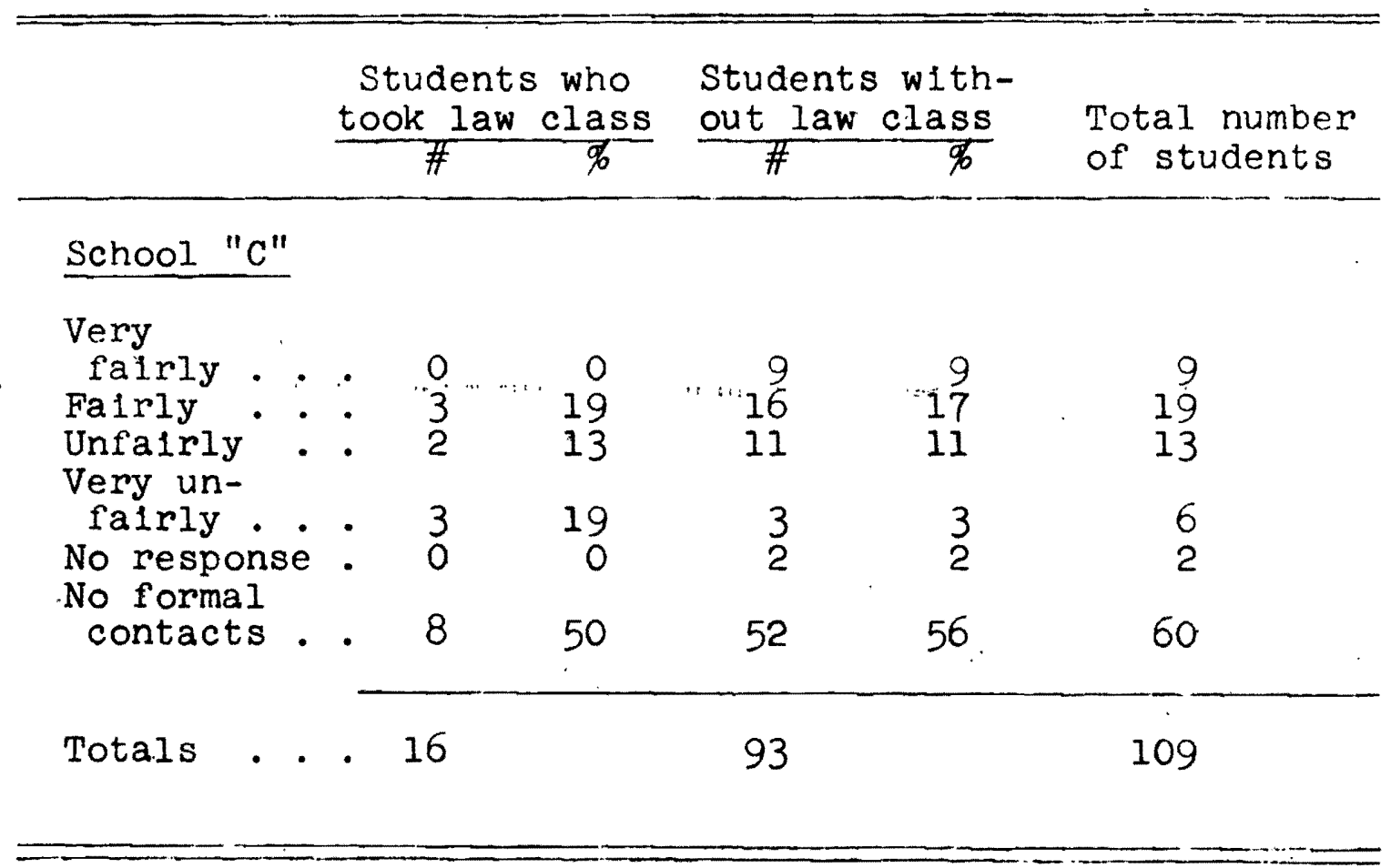

